\title{
Takeover premiums and the perception of auditor independence and reputation
}

\author{
By \\ Martin Bugeja* \\ University of Technology, Sydney
}

\begin{abstract}
This study investigates if there is a positive association between takeover premiums and the bidder's perception of target firm auditor reputation and independence. Using auditor size as a proxy for auditor reputation, the results indicate that in hostile takeovers target shareholders receive a higher takeover premium when a Big 4 auditor audits the target firm prior to the takeover. This result is only significant, however, in the period prior to the highly publicised audit failures. The impact of perceived auditor independence on takeover premiums is studied using the levels and size of non-audit service (NAS) fees provided by the target firm auditor. Using three proxies for auditor independence, the results show no association between perceived auditor independence and takeover premiums. This finding is robust to partitioning the sample by auditor size, takeover hostility and splitting the sample into takeovers preand post- the corporate scandals that occurred in 2002.
\end{abstract}

Key Words: Auditor independence, auditor quality, mergers and acquisitions, takeover premiums

JEL Classifications: G34, M41, M42

\footnotetext{
* Corresponding author: Martin Bugeja, School of Accounting, The University of Technology Sydney, 2007, New South Wales, Australia. Telephone + 6129514 3743, fax + 61295143669 .

E-mail address: martin.bugeja@uts.edu.au. The author acknowledges comments received from two anonymous referees and participants: at a seminar at the Queensland University of Technology, at the 2008 American Accounting Association Annual Meeting and at the 2009 Accounting and Finance Association of Australian and New Zealand Annual Conference.
} 
Takeover premiums and the perception of auditor independence and reputation

\begin{abstract}
This study investigates if there is a positive association between takeover premiums and the bidder's perception of target firm auditor reputation and independence. Using auditor size as a proxy for auditor reputation, the results indicate that in hostile takeovers target shareholders receive a higher takeover premium when a Big 4 auditor audits the target firm prior to the takeover. This result is only significant, however, in the period prior to the highly publicised audit failures. The impact of perceived auditor independence on takeover premiums is studied using the levels and size of non-audit service (NAS) fees provided by the target firm auditor. Using three proxies for auditor independence, the results show no association between perceived auditor independence and takeover premiums. This finding is robust to partitioning the sample by auditor size, takeover hostility and splitting the sample into takeovers preand post- the corporate scandals that occurred in 2002.
\end{abstract}

Key Words: Auditor independence, auditor quality, mergers and acquisitions, takeover premiums

JEL Classifications: G34, M41, M42 


\section{Introduction}

The provision of non-audit services (NAS) by auditors to their clients received worldwide regulatory attention in the early 2000's, following high-profile corporate collapses (e.g., Enron and WorldCom (US) and HIH Insurance (Australia)). Underpinning this regulatory reform is the belief that NAS reduces the quality of financial statements by impairing auditor independence. As stated by the US Securities and Exchange Commission, “an auditor’s independence is impaired either when the accountant is not independent in fact, or when in light of all relevant facts and circumstances, a reasonable investor would conclude that the auditor would not be capable of acting without bias” (SEC 2000). This comment highlights the two dimensions of auditor independence, "independence in fact" and "independence in appearance.” Prior research examining the first dimension of auditor independence provides inconsistent results with the majority of studies finding that NAS does not impair auditor independence (e.g., DeFond, Raghunandan \& Subramanyam 2002; Chung \& Kallapur, 2003; Hay, Knechel \& Li, 2006). Increasingly, more attention is being devoted to the second dimension of auditor independence (e.g., Glezen \& Millar, 1985, Krishnan, Sami \& Zhang, 2005; Khurana \& Raman, 2006).

This paper examines whether the perception of auditor independence impacts on investors' decisions. The context used in this study is the premium offered by bidding firms in Australian hostile takeovers. When a company decides to make a takeover offer, the calculation of the offer price is a crucial decision. In a friendly takeover, the target firm can typically conduct a due diligence of the target firm’s financial affairs. For example, in the 2006 friendly takeover bid for Qantas Airways Limited by Airline Partners Australia, Qantas indicates in its Target Statement "the Board granted due 
diligence and management access to the consortium investors after obtaining confidentiality undertakings." ${ }^{1}$ In contrast, in a hostile takeover, as the bidding firm (and its advisers) do not have access to inside information about the target firm, the pricing decision must be based on publicly available financial information. In these circumstances, it is expected that any doubt over target firm financial statement credibility will flow through to the premium offered. As a result, this context provides an interesting research setting to determine if the provision of NAS affects the perception of auditor independence and, consequently, influences the premium offered by the acquiring firm. Investigating this association in Australia is advantageous as fees received by auditors are a required disclosure. Furthermore, as Australia is less litigious than the US, Australian auditors have less incentive to remain independent due to the lower concern that litigation will harm their reputation (Francis, 2006 and Gul, Tsui \& Dhaliwal, 2006).

The hypothesis of a positive relationship between takeover premiums and auditor independence is tested using audit and NAS fee data for the target firm collected for the year prior to the takeover announcement. The results indicate there is no association between auditor independence and takeover premiums. These findings add to prior research and raise doubts over whether the introduction of regulation to restrict the provision of NAS by auditors was justified.

Findings from previous research indicate that large audit firms provide a higher quality audit (e.g., Palmrose, 1988 and Beatty, 1989) This study extends this line of research by examining if target firms using Big 4 auditors receive a higher takeover

\footnotetext{
${ }^{1}$ Qantas Airways Limited, Target Statement, p 13. Available on the ASX website: http://www.asx.com.au.
} 
premium in hostile bids. In hostile bids the greater financial statement credibility offered by the use of a large auditor is predicted to result in the payment of a higher premium. Furthermore, this study determines if the association between takeover premiums and auditor type was impacted by the auditing failures that occurred in the early 2000’s. The results indicate that in hostile takeovers higher takeover premiums are paid to target firms engaging large auditors. This additional premium however is eliminated in the period following the auditing scandals in the early 2000s. This finding is consistent with a loss in reputation for the large auditing firms following the auditing failures.

The remainder of the paper is structured as follows. Section 2 discusses prior literature and develops hypotheses. The subsequent section discusses the research design and is followed by a description of the data collection process. Section 5 presents the results and the final section of the paper provides a conclusion.

\section{Prior literature and hypotheses development}

\subsection{Auditor reputation and independence}

As auditor reputation is not directly observable, prior research uses auditor size and brand name as an indicator of auditor reputation and quality. The use of size as a proxy for audit quality is advocated by DeAngelo (1981). She argues that, as larger audit firms have a greater potential loss of client specific quasi-rents from breaching audit independence, they have a greater ability to perform their duties free of management's influence. Likewise, size will be a valid proxy for quality because large auditors have an incentive to protect their investment in brand name and reputation (Klein \& Leffler, 1981 and Shapiro, 1983). The findings of prior research 
(e.g. Francis, 1984; Francis \& Stokes, 1986; Palmrose, 1986; Francis \& Simon, 1987;

Gist, 1992; Pong \& Whittington, 1994; Craswell, Francis \& Taylor, 1995; Ashbaugh, LaFond \& Mayhew, 2003 and Choi, Kim, Liu \& Simunic, 2008) of an audit fee premium being paid to large auditors is typically interpreted as being consistent with such auditors providing a higher quality product. $^{2}$

Studies examining the outcomes of the audit process are also consistent with large auditors providing higher quality audits. For example, prior studies indicate that large auditors have a lower incidence of litigation (Palmrose, 1988), ${ }^{3}$ have higher earnings quality (e.g., Becker, DeFond, Jiambalvo \& Subramanyam, 1998; Krishnan, 2003 and Francis \& Wang, 2008) and are associated with lower underpricing in initial public offerings (IPOs) (Balvers, McDonald \& Miller, 1988 and Beatty, 1989). ${ }^{4}$ In addition, Menon and Williams (1991) find that the majority of auditor changes in an IPO are to a large auditor consistent with such auditors increasing financial statement credibility. Furthermore, Lee, Stokes, Taylor and Walter, (2003) show that firms in IPO’s using a large auditor are more likely to provide earnings forecasts.

In the case that an auditor provides NAS to their audit clients, it is argued that cost savings arising from knowledge spillovers create an economic bond between the client and auditor (Simunic, 1984; Beck, Frecka \& Solomon 1988). It is contended that this economic dependence results in the auditor being more willing to

\footnotetext{
${ }^{2}$ Not all studies document a Big 4 audit fee premium. For instance, Antle, Gordon, Narayanamoorthy and Zhou (2006) document otherwise.

${ }^{3}$ In contrast, Lys and Watts (1994) find the probability of litigation is not associated with auditor size.

${ }^{4}$ Chang, Gygax, Oon and Zhang (2008) find greater underpricing in Australian IPO's when a large auditor is used. They interpret this result as indicating that the use of a quality auditor signals a higher after-market value of the newly listed firm.
} 
compromise their independence and acquiesce to the will of management. This contention assumes that the costs of breaching independence (e.g., litigation and loss of reputation) are less than the benefits of client retention. Additionally, it is claimed that, as NAS provides a greater financial return, auditors will not want to take actions that jeopardise this lucrative revenue stream. For example, Arthur Levitt, the chairman of the US SEC, stated, "the audit function is simply being used as a springboard to more lucrative consulting services” (Levitt, 2000).

Research however, has provided inconsistent evidence on whether auditors' independence "in fact” is impaired by higher NAS. For example, prior studies find no association between NAS and audit qualifications (Barkess \& Simnett, 1994; Craswell, 1999; Craswell, Stokes \& Laughton, 2002; DeFond, et al. 2002; Geiger \& Rama, 2003; Hay, et al. 2006; Fargher \& Jiang, 2008; Lim \& Tan, 2008; Robinson, 2008 and Callaghan, Parkash \& Singhal, 2009) and NAS and audit tenure (DeBerg, Kaplan \& Pany, 1991; Barkess et al. 1994 and Hay, et al. 2006). ${ }^{5}$ Other studies, however, provide conflicting evidence and show that higher NAS reduces the likelihood an auditor will provide a going concern opinion (Wines, 1994; Sharma, 2001; Sharma \& Sidhu, 2001 and Basioudis, Papakonstantinou \& Geiger 2008).

Similarly, mixed results have been achieved when investigating accrual quality. A number of studies document that NAS increases discretionary accruals and reduces accrual quality (e.g., Frankel, Johnson \& Nelson, 2002, Gul, Jaggi \& Krishnan 2007, Srinidhi \& Gul, 2007, Cahan, Emanuel, Hay \& Wong, 2008). Other studies however find either no association between discretionary accruals and NAS (Ashbaugh, et al.

\footnotetext{
${ }^{5}$ Beck, Frecka and Solomon (1988) present inconsistent results and find auditor tenure is significantly greater where auditors provide ongoing NAS.
} 
2003; Chung et al. 2003; Larcker \& Richardson, 2004 and Reynolds, Deis \& Francis, 2004) or a negative association (Antle, et al. 2006). Kinney, Palmrose and Scholz (2004) and Bloomfield and Shackman (2008) report a weak association between NAS and earnings restatements. Ruddock, Taylor and Taylor (2006) show that NAS fees are unrelated to earnings conservatism.

Recent research examining if NAS impairs auditors’ actual independence has moved to using fee data at the office level as opposed to the firm level. For example, Li (2009) finds the association between NAS fees and an auditors' propensity to issue a going concern opinion is insignificant pre-SOX and positive post-SOX. Reynolds and Francis (2001) find more important clients at the local level have lower discretionary accruals and lower variance in discretionary accruals. The results of both these studies are inconsistent with auditors compromising independence. Contrasting results, however, are found in a UK study by Ferguson, Seow and Young (2004).

The second aspect of auditor independence, “independence in appearance,” has received additional focus in recent research. Inconsistent with NAS reducing the appearance of independence Glezen et al. (1985) find no association between auditor approval rates and the ratio of NAS fees to audit fees. A negative association between a firm's earnings response coefficient (ERC) and NAS fees is found in Krishnan, et al. (2005), Gul, et al. (2006) and Lim et al. (2008). Francis et al. (2006) report that this association is driven by firms with high accruals whilst Lim et al. (2008) find the relationship is moderated when the auditee engages an industry specialist auditor. In contrast, Ghosh, Kallapur and Moon (2009) show greater client importance arising from audit fees, but not non-audit fees, results in a significantly lower ERC. 
Consistent with NAS impairing the perception of auditor independence, Khurana et al. (2006) and Dhaliwal, Gleason, Heitzman and Melendrez (2008) find that higher NAS fees increase respectively the cost of equity capital and the cost of debt. Studies assessing the impact of the collapse of Enron on other clients of Arthur Andersen have produced mixed findings. Krishnamurthy, Zhou and Zhou (2006) find that amongst Andersen's other audit clients those purchasing greater NAS experienced significantly higher negative abnormal returns around the indictment of Andersen in March 2002. Chaney and Philipich (2002) however find that the amount of NAS purchased by Andersen's other clients is unrelated to abnormal returns around the disclosure in January 2002 that Andersen had shredded a number of documents.

Despite a lack of conclusive findings that NAS fees impinge on auditor independence, regulators worldwide have moved to provide greater controls over the provision of NAS by auditors and calls have been made to prohibit the provision of any NAS by a firm’s auditor (e.g., Francis, 2004). For example, the US Sarbanes-Oxley Act legislated in 2002 prohibited the provision of certain types of services by auditors to their audit client (e.g., internal control). In Australia, audit reforms were put in place in 2004 following CLERP Issue Paper 9 “Corporate Disclosure - Strengthening the Financial Reporting Framework.” The reforms include requirements for auditor partner rotation and a restriction on auditors taking management positions with a former client. The UK also modified auditor independence rules despite there being no high profile local company collapses arising from audit failures. Fearnley and Beattie (2004) discuss these reforms. 


\subsection{Takeover premiums}

Research across many countries documents significant abnormal returns around takeover announcements (e.g., Bugeja; 2005a; Constantinou, Trigeorgis \& Vafeas, 2005 and Bargeron, Schlingemann, Stulz \& Zutter, 2008). Various explanations have been examined to explain the size of takeover premiums. These include cost savings arising from synergies between the target and acquiring firm (e.g., Morck, Shleifer \& Vishny, 1990; Sudarsanam, Holl \& Salami, 1996 and Hietala, Kaplan \& Robinson, 2003), and the disciplining of inefficient or underperforming target management (e.g., Agrawal \& Jaffe, 2003 and Harford, 2003).

The association between the quality and credibility of accounting information and takeover premiums, including the role of the target firm auditor, remains largely unexplored. Raman, Shivakamur and Tamayo (2008) report a negative association between target firm earnings quality and takeover premiums in negotiated bids and an insignificant finding in non-negotiated bids. Their explanation of the results is that information obtained in negotiations is likely to be more useful for targets with poor earnings quality than for those with high earnings quality. Louis (2005) finds that bidding firms using a non-Big 4 auditor have higher takeover announcement returns. The finding is consistent with smaller auditors being able to provide superior takeover advice due to their more specialised knowledge of their local communities and clients.

Bugeja (2005b) investigated independent expert valuation reports provided by Australian target firms. The results indicated that the frequency with which the opinion provided by the expert agreed with the recommendation of the target firm board was indifferent between reports authored by the target firm auditor and other 
experts. The market reaction to the release of the expert report however was only significant if the expert report was produced by a firm other than the target firm auditor. This finding indicates that the perception of auditor independence is important in establishing the credibility of information provided during a takeover.

Anderson, Stokes and Zimmer (1993) and Firth (1999) examine the choice of auditor by the acquiring firm following a successful takeover in Australia and the UK respectively. Both studies find that the vast majority of acquiring firms choose to switch auditors to their own incumbent. Firth (1999) finds that the acquiring firm is more/(less) likely to change auditors when it engaged a large/(small) audit firm prior to the takeover and the target engaged a small/(large) auditor. These results are consistent with acquiring firms perceiving large audit firms as having better quality.

In a takeover a bidder is faced with information asymmetry over the "true value" of the target firm. In a friendly takeover, the bidding firm can typically reduce the level of information asymmetry by conducting a due diligence. In contrast, in hostile takeovers a bidder must rely on the target firm financial statements to value the target firm. It is predicted that the degree of reliance on and confidence in this publicly available information will be influenced by the perceived quality of the financial statements. As the function of an auditor is to attest to the financial statement information, this study argues that a greater level of credibility will be added to the target firm financial report when the target auditor is perceived by the acquiring firm as having a better reputation and a higher level of independence. 
The prior literature on auditor reputation indicates that target firm financial statements have greater perceived credibility when a large auditor audits the firm. Additionally, previous studies and regulatory concerns over the impact of NAS on the appearance of auditor independence suggest that financial statement credibility will be reduced when an auditor provides an increasing amount of NAS to an audit client. This leads to the two hypotheses tested in this study:

H1: In hostile takeovers takeover premiums are negatively related to the amount of NAS provided by the target firm auditor;

$H 2$ : In hostile takeovers takeover premiums are positively related to the size of the target firm auditor.

The reputation or independence of the target auditor is not expected to play an important role in friendly bids as the role of external financial information is lower in these takeovers. Notwithstanding this expectation, we test the impact of auditor independence and reputation in both hostile and friendly takeovers.

A possible countervailing influence when testing Hypothesis One is that firms purchasing greater amounts of NAS will have firm characteristics that attract a takeover offer. For instance, complex target firms or firms in the process of restructuring are more likely to purchase NAS. If these firm characteristics are also 
associated with the likelihood of becoming a takeover target, then NAS will result in higher rather than lower takeover premiums. ${ }^{6}$

\section{Research design}

Takeover premiums (Prem) are calculated for Australian target firms by subtracting the return on the All Ordinaries Accumulation Index over the period commencing 60 days prior to the takeover announcement and ending 30 days afterwards from the target firm returns over the same period. ${ }^{7}$ The Core Research Database maintained by the Securities Industry Research Centre of Asia-Pacific (SIRCA) was used to source target firm share prices.

The testing of Hypothesis One requires a proxy for the appearance of target firm auditor independence (AUDINDEP). If target firm auditor independence is an issue for the acquiring firm, then an assessment of independence is likely to be conducted using the target firm NAS fee disclosures. As stated by Ashbaugh, et al. (2003), the perception of independence as viewed by regulators and the general public is more likely to be captured by the fee ratio than the total fees paid by a firm to an auditor at either the audit firm level or audit office level. The first two measures of auditor independence are variants of the fee ratio used in earlier research. The first proxy takes the ratio of NAS fees to total fees (RNASTOT), whilst the second proxy is the ratio of NAS fees to audit fees (RNASAUD). The final measure of auditor independence is the natural logarithm of the NAS fee (LNNAS). All three measures are observed at the target firm level and are hand collected from the most recent

\footnotetext{
${ }^{6}$ We thank an anonymous referee for highlighting this alternative prediction for NAS and takeover premiums.

${ }^{7}$ The companies included in the index represent over 95\% (by value) of companies listed on the Australian Securities Exchange. The index assumes all dividends are reinvested into the stock.
} 
annual financial statements available to the Australian Securities Exchange (ASX)

before the takeover announcement. ${ }^{8}$ Annual reports are sourced from Huntley’s

Aspect FinAnalysis database.

Hypothesis Two is tested using an indicator variable which denotes target firms audited by a large auditor (AUDREP). ${ }^{9}$ The identity of the auditor preceding the takeover announcement is collected from the most recent target firm financial report issued before the takeover announcement. ${ }^{10,11}$

Financial statement credibility will be reduced if the auditor has issued a qualified audit opinion. A dummy variable (QUALIFIED) is used to indicate takeovers in which the target auditor issued a qualified audit opinion on the financial statements for the year prior to the takeover. ${ }^{12}$ As a control for target firm earnings quality (EARNQUAL), we use the ratio of cash flows from operations to profit after tax. ${ }^{13}$

Earlier studies have identified additional variables which need to be controlled for in a model of takeover premiums. As cash takeovers expose shareholders to an immediate

\footnotetext{
${ }^{8}$ Audit and NAS fees are a required disclosure in Australia for the entire sample period.

${ }^{9}$ Over the period of this study (i.e., 1996 to 2006), the number of large auditing firms decreased from six to four following the merger of Coopers and Lybrand with Price Waterhouse in 1997 and the demise of Arthur Andersen in 2002. The AUDREP variable is coded as one for target firms audited by any of these audit firms.

${ }^{10}$ To ensure that the auditor at the date of the takeover was identical to that which was engaged on the financial statements released prior to the takeover announcement, a search was made of announcements made to the ASX to identify auditor switches. A change in auditor was identified for one target firm, which was deleted from the sample.

${ }^{11}$ As the purpose of this study is to focus on whether the appearance of auditor independence and reputation influence takeover premiums, we do not include measures of actual auditor quality or independence (e.g., discretionary accruals or the rate of client audit report qualifications by audit firm). Instead, we focus on measures of independence and reputation easily observable by an investor.

${ }^{12}$ For the purposes of this study a qualification was defined to include both a qualified opinion and a statement from the auditor that there is an inherent uncertainty in the accounts (e.g., due to going concern issues). Audit qualifications were identified by reading through the auditor's report attached to the financial statements.

${ }^{13}$ All accounting information needed to measure the variables in the model is collected from the financial statements released for the financial year immediately preceding the takeover announcement.
} 
tax liability, they have been documented to be associated with increased takeover premiums (e.g., Huang \& Walkling, 1987; Franks, Harris \& Mayer, 1988; Draper \& Paudyal, 1999; Da Silva Rosa, Izan, Steinback \& Walter, 2000 and Bugeja, 2005a). Method of payment (PAYT) is controlled using an indicator variable denoting takeovers in which the takeover consideration is exclusively cash. The payment type is identified from bidder takeover documents lodged with the ASX.

The Bidders Statement lodged with the ASX is used to obtain the bidding firm toehold interest (TOEHOLD) in the target. Previous research suggests a negative association between takeover premiums and the bidder's toehold (Stulz, 1988; Stulz, Walkling \& Song 1990; Bugeja \& Walter 1995; and Sudarsanam, et al. 1996). Competing takeover offers for a target are identified using an indicator variable coded as one (MULTIPLE) if there is more than one simultaneous bidder for the target. It is expected that takeover premiums will be higher when there are multiple bidders.

Following the approach of Schwert (2000), target firm return on equity (ROE) is used as a control for firm performance. As in Schwert (2000) and Bugeja (2005a), target firm growth is proxied using the target firm market-to-book ratio $(M B)$. The natural logarithm of target firm market capitalisation (TGTSIZE) is included as a control for size. ${ }^{14}$ Prior research has found that target size is negatively related to takeover premiums in Australia (Anderson, Haynes \& Heaney, 1994) and insignificant in the US (Betton, Eckbo \& Thorburn, 2009). The previous two variables are measured as at balance date for the financial year end before the takeover announcement.

\footnotetext{
${ }^{14}$ The results are not sensitive to measuring size or market-to-book using the market capitalisation of the target firm two months prior to the takeover announcement.
} 
Israel (1991) and Israel (1992) argue that firms with higher leverage will have a more concentrated share ownership structure resulting in higher takeover premiums.

Leverage is included in the model using the target firm debt to equity ratio $(D E)$. To control for the target firm information environment, a dummy variable is used indicating target firms which had analyst following for the financial year-ended prior to the takeover (ACOV) announcement. Analyst following information is obtained from the IBES historical database. The model includes target firm bankruptcy risk measured using the Altman (1968) bankruptcy prediction model (ALTZ). Earlier research shows that takeover premiums are lower for target firms with higher bankruptcy risk (Amit, Livnat \& Zarowin, 1989). Year and industry indicator variables are included in the model to control for year and industry effects.

The full model estimated separately for hostile and friendly takeovers is:

PREM $_{i}=\alpha_{i}+\beta_{1}$ AUDINDEP $_{i}+\beta_{2}$ AUDREP $_{i}+\beta_{3}$ QUALIFIED $_{i}+\beta_{4}$ EARNQUAL $_{i}+$ $\beta_{5}$ PAYT $_{\mathrm{i}}+\beta_{6}$ TOEHOLD $_{\mathrm{i}}+\beta_{7}$ MULTIPLE $_{\mathrm{i}}+\beta_{8} \mathrm{DE}_{\mathrm{i}}+\beta_{9} \mathrm{ROE}_{\mathrm{i}}+\beta_{10} \mathrm{MB}_{\mathrm{i}}+$

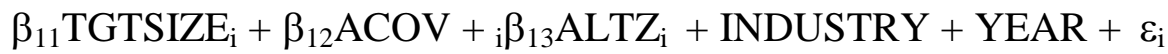
where AUDINDEP is defined alternately as the:

RNASTOT Ratio of NAS fees to total fees paid to the target firm auditor RNASAUD Ratio of NAS fees to audit fees paid to the target firm auditor LNNAS Natural log of NAS fees

To control for heteroskedasticity, all reported $t$-statistics from estimating the takeover premium model are based on White’s (1980) consistent covariance estimator. 


\section{Sample and descriptive statistics}

All takeovers for ASX listed firms from 1996 to 2006 are identified from the Connect 4's Mergers and Acquisitions Database. ${ }^{15}$ This search identified 593 takeovers. The announcement date of the takeover was found by searching through announcements made to the ASX available on Huntley's Aspect FinAnalysis database. It was necessary to exclude takeovers that had insufficient information available to estimate model (1) leaving 547 takeovers in the final sample. A takeover was classified as hostile if the initial recommendation of the target firm board in its Target Statement to shareholders was that the offer be rejected. A temporal distribution of the sample partitioned by the attitude of the target firm board is provided in Panel A of Table 1.

\section{INSERT TABLE 1 HERE}

There is no discernible trend in takeover activity with the number of takeovers at their highest in the first and last year of the sample. Approximately $48 \%$ of offers are hostile. It is noticeable, however, that the frequency of hostile takeovers varies across years. Panel B of Table 1 presents a distribution of target firms classified into the 24 ASX industry sector codes. Within the sample, $13 \%$ of the targets are involved in gold mining and 16\% are classified as miscellaneous industrials.

Table 2 presents descriptive statistics for the variables incorporated into model (1). Consistent with earlier studies, (e.g., Bargeron, et al. 2008; Bugeja 2005a and Constantinou, et al. 2005) target shareholders receive significant positive abnormal returns around the takeover announcement with the mean and median return being

\footnotetext{
${ }^{15}$ No private target firms are included in the sample.
} 
$27 \%$ and $23 \%$ respectively. On average, NAS fees are $34 \%$ of the total fee received by the target firm auditor. ${ }^{16}$ This statistic is slightly higher than the ratio of $29 \%$ reported in the Australian study by Ruddock, et al. (2006). ${ }^{17}$ The statistics for RNASAUD indicate that the average fee paid for NAS is approximately equal to the audit fee, raising the possibility that financial statement users perceive an impairment of audit independence. However, NAS fees have a wide range relative to audit fees, ranging from zero to being over twelve times as large. Big 4 auditors are engaged by $76 \%$ of target firms. Approximately $8 \%$ of target firms are issued with a qualified audit report in the year prior to the takeover. ${ }^{18}$ Mean and median target firm market capitalisation are respectively \$332 million and \$50.9 million.

\section{INSERT TABLE 2 HERE}

The last three columns of Table 2 compare averages for each variable across auditor type. The comparison indicates that large auditors provide a significantly higher level of NAS than small auditors. In addition, and as would be expected, clients of Big 4 auditors are significantly larger, have lower bankruptcy risk and are more likely to have analyst following. Providing initial evidence consistent with Hypothesis 2, takeover premiums are significantly higher for targets audited by a Big 4 auditor. ${ }^{19}$

\footnotetext{
${ }^{16}$ It is not possible to provide a breakdown of NAS fees into different categories of NAS as the vast majority of disclosures of NAS fees simply provide a total of other fees paid to auditors. It was only after the introduction of the CLERP reforms in 2004 that the details of NAS fees had to be provided. ${ }^{17}$ The difference in RNASTOT in this study to that found in Ruddock et al. (2006) is likely a result of sample composition. This study consists of target firms which are generally relatively smaller entities. Further, the sample period between the two studies is inconsistent.

${ }^{18}$ Approximately $70 \%$ of these observations are a statement by the auditor that the entity is subject to inherent uncertainty due to going concern issues.

${ }^{19}$ As a means of comparison with the target firms in the sample Huntley's Aspect FinAnalysis database was used to obtain median values for: the natural logarithm of market capitalisation, return on equity, debt-to-equity and market-to book ratios for non-sample firms for the period 1996 to 2006. The median values were respectively: 17.13, 1.94\%, 9.22\% and 1.24 .
} 
Correlation coefficients between the dependent and independent variables in model (1) are presented in Table 3. The correlation between takeover premiums and the three measures of auditor independence do not support Hypothesis One. The only significant correlation (LNNAS) is positive and not the predicted negative sign. As expected, there is a high degree of correlation between the three measures of auditor independence. Consistent with Hypothesis Two, the correlation between the takeover premium and auditor reputation is positive and significant. There is a significant positive correlation between the use of large audit firms and the three auditor independence measures. Although there is significant correlation between various control variables, the size of the correlation indicates that multicollinearity will not be a problem with the estimation of model (1) (Gujarati, 1995).

\section{INSERT TABLE 3 HERE}

\section{Results}

\subsection{Estimation of the takeover premium model}

The results of estimating regression model (1) are presented in Panels A and B of Table 4 for respectively hostile and friendly takeovers. Given the significant correlation between each auditor independence measure and auditor size the model is estimated separately to test each Hypothesis. ${ }^{20}$ The test of Hypothesis One, which uses sequentially each proxy for auditor independence, is shown in columns (1) through (3). The results in Panel A provide no support for Hypothesis One. The findings from testing Hypothesis Two are presented in column (4). The coefficient on the large auditor dummy variable is positive and significant. The size of the

\footnotetext{
${ }^{20}$ The conclusions do not change if auditor size is included in model (1) with alternatively each auditor independence proxy.
} 
coefficient indicates that target shareholders receive an additional premium of $8.3 \%$ when a reputable auditor audits the target firm.

\section{INSERT TABLE 4 HERE}

The results for friendly takeovers are provided in Panel B of Table 4. Similar to the results for hostile takeovers, the coefficient on the auditor independence measures are insignificant. Additionally, the auditor reputation variable is insignificant. This finding indicates that if bidders are able to make their own assessment on financial statement credibility, the target firm auditor reputation is unimportant in offer pricing.

In both hostile and friendly takeovers, target firm abnormal returns are positively related to the target firm debt-to-equity ratio and negatively associated with the target firm market-to-book ratio. The negative impact of market-to-book is possibly explained by bidders offering a lower premium when target value represents growth options as the potential for overpayment is higher in these circumstances. The positive relationship between takeover premiums and target firm leverage is consistent with the results in Raad, Ryan and Sinkey (1999).

The significant findings for many of the other controls are sensitive to whether the bid is hostile or friendly. For instance, the earnings quality measure is positively related to takeover premiums in friendly bids and negatively associated in hostile takeovers. These findings are inconsistent with the US findings in Raman, et al. (2008). A possible interpretation of our findings is that in friendly takeovers the bidder through due diligence is able to substantiate the level of earnings quality and is willing to pay 
a higher premium due to the lower risk of earnings not being realised as cash flows post- takeover. In contrast, in hostile bids as the bidding firm cannot access the records of the target firm, it discounts the value of high quality earnings due to its inability to verify the accuracy of the information. ${ }^{21}$

In friendly takeovers, there is a negative association between target firm return on equity and takeover premiums. In contrast, target firm performance is insignificant in hostile bids. These results suggests bidding firms are willing to pay a higher premium for an underperforming firm only if the target management are supportive of the takeover. Additionally, in hostile bids takeover premiums are higher in takeovers when cash is offered as payment and the bidder has a lower toehold. These variables are, however, insignificant in friendly takeovers. The results in Henry (2005) provide a partial explanation for the differences in findings across target firm attitude to the takeover. That study finds that accept recommendations in Australian takeovers are significantly more likely when equity is offered as payment and the acquiring firm has a higher toehold. It is, therefore, expected that the impact on premiums of cash payment and low toeholds will be higher in the reject sub-sample.

In friendly takeovers, analyst coverage and target firm size are respectively positively and negatively related to takeover premiums. However, these variables are insignificant in hostile bids. The negative association for target firm size is consistent with the results in Anderson, et al. (1994). They use an information asymmetry explanation for the negative effect of target firm size on takeover premiums arguing

\footnotetext{
${ }^{21}$ The findings for the earnings quality measure must be interpreted in the light of the unsophisticated measure of earnings quality employed in this study. As assessing the association between earnings quality and takeover premiums is not the primary purpose of this study, it is left to further research to examine the relationship between more sophisticated earnings quality measures (e.g., Dechow and Dichev, 2002) and takeover premiums.
} 
that a takeover announcement contains more information content for a smaller firm. The Altman (1968) measure of bankruptcy risk is insignificant in friendly takeovers and negative in hostile takeovers. The negative sign on bankruptcy risk is surprising and inconsistent with the results in Amit et al. (1989). One possible explanation is that target firms with a higher risk of bankruptcy have a greater potential for posttakeover performance improvements.

\section{Pre- and post- the audit failures}

The audit failures that occurred in the early 2000s led to a wave of regulation which placed restrictions on the provision of NAS by auditors. It is likely that these audit failures both damaged the reputation of large accounting firms and highlighted the potential independence issues resulting from the provision of NAS. If these highly publicised audit failures focused bidding firms on the amount of NAS provided by target auditors, the greatest negative effect of NAS on takeover premiums will be found in hostile takeovers subsequent to the audit failures. Furthermore, the perception that large auditors had a superior reputation is likely to have been tarnished following the adverse publicity surrounding these high profile audit failures. As a result of this tarnished brand name it is possible that bidders would no longer be willing to pay an additional premium for targets audited by a Big 4 auditor.

To test whether the results of the two hypotheses are sensitive to whether the takeover was announced before or after the auditing scandals, we introduce a dummy variable into regression model (1) that denotes takeovers announced from 2002 onwards (POST01). This dummy variable is then interacted respectively with each of the three auditor independence measures and the auditor reputation variable. The findings from 
estimating this regression model are given in Table 5 with the results for hostile and friendly takeovers respectively in Panels A and B.

\section{INSERT TABLE 5 HERE}

The results continue to provide no support for Hypothesis One with all three measures of auditor independence insignificant both before and after 2002. The impact of auditor reputation on takeover premiums continues to be insignificant in friendly takeovers. In hostile bids, however, the results are found to be sensitive to the time period during which the takeover was announced. Although the coefficient on AUDREP is positive and significant, the interaction of this variable with POST01 indicates a decline in the importance of auditor reputation in explaining takeover premiums after the auditing scandals. This finding indicates that in the 'minds' of bidding firms the audit scandals diminished the reputation of the large auditing firms to the extent that the financial statements of their auditees were no more credible than those of other auditors. The results on the control variables are largely unchanged from those shown in Table 4. The coefficient on POST01 is insignificant indicating no temporal change in takeover premiums in the second half of the sample period.

\subsection{Sensitivity tests and additional analysis}

\section{Deletion of zero NAS observations}

Approximately 70 (12.8\%) target firms do not purchase any NAS from their auditors.

To assess if the results are sensitive to the inclusion of these observations, the analysis is repeated after excluding these firms. The results (not tabulated) are qualitatively unchanged from those presented. 


\section{Target firms with 'high' NAS fees}

To assess if auditor independence concerns only impact on takeover premiums when NAS fees are relatively high, the sample is partitioned at the median for each of the proxies for auditor independence. The results are then re-estimated using only those observations above the median. The coefficients (not tabulated) on each auditor independence proxy remained insignificant. ${ }^{22}$

\section{Large vs small auditors}

To examine if the effect of NAS on the appearance of auditor independence differs between Big4/non-Big 4 auditors, the sample was partitioned by auditor size and model (1) estimated for each auditor type. For both types of auditor, the results for all three measures of auditor independence were insignificant.

\section{Industry specialists and second tier auditors}

Prior research is consistent with auditor industry specialists receiving an audit fee premium (e.g., Craswell, et al. 1995; Ferguson \& Stokes, 2002; Ferguson, Francis \& Stokes, 2003; Francis, Reichalt \& Wang, 2005; Basioudis \& Francis, 2007; Carson \& Fargher, 2007 and Carson, 2009). ${ }^{23}$ Lim et al, (2008) report that industry specialist auditors are more likely to issue a going concern opinion in the presence of higher NAS, consistent with industry specialists demonstrating greater concern with protecting their reputation. Reichult and Wang (2010) find that when an auditor is both a country and city-specific industry specialist, audit quality is increased. To determine if additional takeover premiums are received by target firms engaging a

\footnotetext{
${ }^{22}$ The sample was also partitioned into quartiles for each of the auditor independence variables and the takeover premium model estimated for the highest quartile. The coefficients on the auditor independence measures continued to be insignificant.

${ }^{23}$ Across these studies, the results vary as to whether the industry specialist auditor fee premium is received at either or both the city level and national level.
} 
specialist auditor, the regression analysis was repeated using only target firms with a Big 4 auditor. In this analysis, the auditor reputation variable was replaced with an industry specialist variable. The industry specialist was identified by taking all ASX listed firms in each year of the sample and defining the lead auditor in each industry in terms of total audit fees received as the industry specialist. The coefficient on the industry specialist variable was insignificant. ${ }^{24}$

Basioudis et al. (2007) reports that second tier accounting firms (i.e., Grant Thornton and BDO) receive a fee premium relative to third tier firms. Therefore, it is possible that target firms engaging second tier auditors earn higher abnormal returns than those using third tier auditors. To test this proposition, the regression model was adapted by including a dummy variable denoting targets audited by either Grant Thornton or BDO. The results on the second tier dummy variable were insignificant and the conclusions from the auditor reputation variable were unchanged. ${ }^{25}$

\section{Listing status of the bidder}

The results presented include takeovers from both listed and unlisted bidders. To determine if the listing status of the bidder influenced the results, the analysis was reestimated after including a dummy variable identifying listed bidders. The coefficient on this variable was insignificant and the conclusion drawn from the other variables remained unchanged. Additionally, the analysis was undertaken only for listed bidders. The results were consistent with those presented in Tables 4 and 5. As part of the analysis for listed bidders, two additional control variables were included in the

\footnotetext{
${ }^{24}$ An industry specialist was defined alternatively as the auditor with the greatest number of clients in an industry. The industry specialist variable remained insignificant.

${ }^{25}$ The second tier auditor dummy was also expanded to include PKF Chartered Accountants. The coefficient remained insignificant.
} 
regression model. The first variable was the relative size of the target to the bidder, which reported an insignificant coefficient. The other variable was an indicator variable denoting takeovers in which the target and bidder were in similar industries. This variable was positive and significant consistent with there being greater synergies when firms in related industries merge.

\section{Measure of abnormal returns}

Abnormal returns were also calculated over the following event windows around the takeover announcement: -60 days through +10 days; -30 days through +30 days and 10 days through +10 days. Regression model (1) was then re-estimated using each of the alternative event windows. The results were in line with those presented. As an additional test, abnormal returns were also measured using the market model with parameter coefficients estimated over the period -205 through -90 days prior to the takeover announcement. Model (1) was then estimated for both the original event window and the additional event windows described above. The results were once again consistent with the results in Tables 4 and 5.

\section{Identical auditors}

In situations that the same auditor audits the target and bidding firm, it is possible that the acquiring firm will be more confident of the level of credibility of the target firm financial statements. To examine if having an identical auditor impacts on takeover premiums, model (1) was re-estimated including an additional dummy variable denoting identical auditors. The coefficient on this variable was insignificant. ${ }^{26}$

\footnotetext{
${ }^{26}$ This testing required the exclusion of takeovers with bidders not listed on the ASX. Of the remaining 316 takeovers, identical auditors were present in 67 (21\%) of cases.
} 


\section{Different auditor quality between the target and bidder}

After a successful takeover, most targets will switch to the bidder's auditor (Anderson, et al. 1993 and Firth, 1999). If share prices are discounted because of lower quality auditing, it is possible that target firms audited by a small auditor will experience higher abnormal returns when it receives a takeover from a bidder with a large auditor. Testing this conjecture, we re-estimated model (1) including a dummy variable denoting takeovers in which the acquiring firm engages a large auditor and the target firm uses a small auditor. ${ }^{27}$ This variable was insignificant. ${ }^{28}$

\section{Does auditor reputation return to significance?}

The results in Table 5 indicate that post 2001, the impact of auditor reputation on takeover premiums declined. To examine if the reputation of auditors improved in the later years of the sample, model (1) was re-estimated for hostile takeovers alternatively for the period 2004 to 2006 and 2005 and 2006. In both cases, the coefficient on AUDREP was insignificant.

\section{Qualified opinions and the independence of auditors}

In the case that a qualified audit opinion is issued by the auditor, there is likely to be lower concern that the auditor is not acting independently. As a result, Hypothesis 1 is less likely to be supported for these target firms. To ensure target firms with qualified audit reports did not influence the results, the analysis was undertaken after excluding targets with qualified audit opinions. The findings were unchanged.

\footnotetext{
${ }^{27}$ This analysis was conducted using only takeovers in which the bidding firm was listed on the ASX.

${ }^{28}$ A dummy variable was also used to determine if targets earned a lower abnormal return if they had a Big 4 auditor and the acquiring firm had a non-Big 4 auditor. The result was insignificant.
} 


\section{Target firms in financial distress}

Prior evidence suggests that auditors receiving higher NAS are less likely to issue a going concern qualification to firms in financial distress (e.g., Sharma et al. 2001 and Basioudis et al. 2008). If auditors are more likely to compromise their independence in this situation, it would be expected that firms making a takeover of a financially distressed target would have heightened concerns regarding auditor independence. To assess if this is the case, Hypothesis One is examined by restricting the sample to target firms considered to be in financial distress. As in DeFond et al. (2002) financial distress is defined as firms reporting negative cash flow from operations or a net loss in the financial report issued in the year prior to the takeover announcement. The coefficients on the auditor independence variables remained insignificant. ${ }^{29}$

\section{Dated financial information}

The accounting information, auditor reputation and auditor independence variables in the regression models are extracted from the last set of target financial statements released prior to the takeover announcement. A possible issue arising therefore is that the information is dated and no longer relevant when the takeover is announced. This issue is addressed in two ways. Firstly, a time lag variable is included in the regression model. This variable is calculated as the natural logarithm of the number of days between the financial statement balance date and the takeover announcement date. The coefficient on this variable was insignificant and the conclusions drawn from the other variables were unchanged. Secondly, the regression models were re-

\footnotetext{
${ }^{29}$ Alternative definitions of financial distress were also employed. In each case, the coefficients on the auditor independence variables remained insignificant. One alternative definition of financial distress was those target firms with negative retained earnings or negative working capital. A second definition was to limit the sample to targets with a going concern opinion and a matched target firm. The match was identified as the target firm in the same industry with the closest Altman (1968) z-score.
} 
estimated using only takeovers announced within six months of the release of the previous financial statements. The conclusions remained identical to those presented.

\section{Self-selection bias}

One possible concern with the finding of a positive association between Big 4 auditors and takeover premiums is that characteristics associated with the choice of a large auditor are driving the findings. To control for self-selection, model (1) was reestimated after including the number of subsidiaries and the proportion of foreign subsidiaries controlled by the target firm at balance date for the year prior to the takeover. These variables are measures of complexity and partially control for the choice of a Big 4 auditor. The coefficients on both these variables were insignificant and the other results remained unchanged. Notwithstanding this finding it is still possible that the findings for Hypothesis Two are driven by self-selection.

\section{Pooled sample}

The analysis was also repeated for the full sample with the inclusion of an indicator variable indicating takeovers where the initial recommendation of the target board is offer acceptance. The coefficient on the board recommendation and the auditor independence measures were insignificant. The findings for the auditor reputation variable were identical to those shown in Tables 4 and 5.

\section{Discussion and conclusions}

This study extends recent research assessing whether NAS impairs the "appearance” of auditor independence. The context used is the hostile takeover of a publicly listed company as this involves a major corporate investment decision undertaken in an 
environment of information uncertainty. The results show no association between target firm NAS and takeover premiums. This finding indicates that bidding firms do not perceive that higher NAS impacts financial statement quality and credibility or, if it does, the reduction in credibility is insufficient to influence their pricing decision. From a policy perspective this result indicates that regulatory action restricting NAS may have been unjustified. An alternative explanation for the findings in this study is that firm characteristics associated with the purchase of NAS result in a firm becoming subject to a takeover offer. If these characteristics lead to higher takeover premiums, this effect will counteract any negative impact arising from independence concerns.

This study also analyses whether targets using a more reputable auditor receive a higher takeover premium. The results indicate that premiums in hostile takeovers are significantly higher when a large auditor audits the target. This result, however, is only significant in the period prior to the corporate failures that occurred in the early part of this century. This finding is consistent with these accounting scandals tarnishing the reputation of large auditing firms to the extent that the credibility of target firm financial statements was considered equivalent across auditor firm size. 


\section{References}

Agrawal, A., Jaffe, J. (2003). Do takeover targets underperform? Evidence from operating and stock returns. Journal of Financial and Quantitative Analysis, 38(4), 721-746.

Altman, E. (1968). Financial ratios, discriminant analysis and the prediction of corporate bankruptcy. The Journal of Finance 23(4), 589-609.

Amit, R., Livnat, J., Zarowin, P. (1989). A classification of mergers and acquisitions by motives: Analysis of market responses. Contemporary Accounting Research 6(1), 143-158.

Anderson, D., Haynes, A., Heaney, R. (1994). Company takeovers and equity returns: The target size effect. Australian Journal of Management 19(1), 1-30. Anderson, D., Stokes, D., Zimmer, I. (1993). Corporate takeovers and auditor switching. Auditing: A Journal of Practice \& Theory 12(1), 65-73.

Antle, R., Gordon, E., Narayanamoorthy G., Zhou, L. (2006). The joint determination of audit fees, non-audit fees, and abnormal accruals. Review of Quantitative Finance and Accounting 27(3), 235-266.

Ashbaugh, H., LaFond, R., Mayhew, B. (2003). Do nonaudit services compromise audit independence? Further evidence. The Accounting Review 78(3), 611-639. Balvers R., McDonald B., Miller, R. (1988). Underpricing of new issues and the choice of auditor as a signal of investment banker reputation. The Accounting Review 63(4), 605-622.

Bargeron, L., Schlingemann F., Stulz, R., Zutter, C. (2008). Why do private acquirers pay so little compared to public acquirers? Journal of Financial Economics 89(3), 375-390. 
Barkess, L., Simnett, R. (1994). The provision of other services by auditors: independence and pricing issues. Accounting and Business Research 24(Spring), 99108.

Basioudis, I., Francis, J. (2007). Big 4 audit fee premiums for national and officelevel industry leadership in the United Kingdom. Auditing: A Journal of Practice and Theory 26(2), 143-166.

Basioudis, I., Papakonstantinou, E., Geiger, M. (2008). Audit fees, non-audit fees and auditor going-concern reporting decisions in the United Kingdom. Abacus 44(3), 284309.

Beatty, R. (1989). Auditor reputation and the pricing of initial public offerings. The Accounting Review 64(4), 693-709.

Beck, P., Frecka, T., Solomon, I. (1988). A model of the market for MAS and audit services: Knowledge spillovers and auditor-auditee bonding. Journal of Accounting Literature 7, 50-64.

Becker, C., Defond, M., Jaimbalvo, J., Subramanyam, K. (1998). The effect of audit quality on earnings management. Contemporary Accounting Research 15(1), 1-24. Betton, S., Eckbo, B., Thorburn, K. (2009). Merger negotiations and the toehold puzzle. Journal of Financial Economics 91(2), 158-178.

Bloomfield, D., Shackman, J. (2008). Non-audit service fees, auditor characteristics and earnings restatements. Managerial Auditing Journal 23(2), 125-141.

Bugeja, M. (2005a). Effect of independent expert reports in Australian takeovers. Accounting and Finance 45(4), 519-536.

Bugeja, M. (2005b). The 'independence' of expert opinions in corporate takeovers: agreeing with directors’ recommendations. Journal of Business Finance and Accounting 32(9\&10), 1861-1885. 
Bugeja, M., Walter, T. (1995). An empirical analysis of some determinants of the target shareholder premium in takeovers. Accounting and Finance 35(2), 33-60. Cahan, S., Emanuel, D., Hay, D., Wong, N. (2008). Non-audit fees, long-term auditor-client relationships and earnings management. Accounting and Finance 48(2), 181-207.

Callaghan, J., Parkash, M., Singhal, R. (2009). Going-concern audit opinions and the provision of non-audit services: Implications for auditor independence of bankrupt firms. Auditing: A Journal of Practice and Theory 28(1), 153-169.

Carson, E. (2009). Industry specialization by global audit firm networks. The Accounting Review 84(2), 355-382.

Carson, E., Fargher, N. (2007). Note on audit fee premiums to client size and industry specialization. Accounting and Finance 47(3), 423-446.

Chaney, P., Philipich, K. (2002). Shredded reputation: The cost of audit failure. Journal of Accounting Research 40(4), 1221-1245.

Chang, X., Gygax, A., Ooon, E., Zhang, H. (2008). Audit quality, auditor compensation and initial public offer underpricing. Accounting and Finance 48(3), 391-416.

Choi, J., Kim, J., Liu, X., Simunic, D. (2008). Audit pricing, legal liability regimes, and Big 4 premiums: Theory and Cross-Country evidence. Contemporary Accounting Research 25(1), 55-99.

Chung H., Kallapur, S. (2003). Client importance, nonaudit services, and abnormal accruals. The Accounting Review 78(4), 931-955.

Constantinou, C., Trigeorgis, L., Vafeas, N. (2005). Target board structure and takeover-induced abnormal returns in the UK. Corporate Ownership and Control 3(1), 101-113. 
Craswell, A. (1999). Does the provision of non-audit services impair auditor independence? Journal of International Auditing 3(1), 29-40.

Craswell, A., Francis, J., Taylor, S. (1995). Auditor brand name reputations and industry specializations. Journal of Accounting and Economics 20(3), 297-322. Craswell, A., Stokes, D., Laughton, J. (2002). Auditor independence and fee dependence. Journal of Accounting and Economics 33(2), 253-275.

Da Silva Rosa, R., Izan, H., Steinback, A., Walter, T. (2000). The method of payment decision in Australian takeovers: An investigation of causes and consequences. Australian Journal of Management 25(1), 67-94.

Davis, S., Hollie, D. (2008). The impact of nonaudit service fee levels on investors’ perception of auditor independence. Behavioral Research in Accounting 20(1), 31-44. DeAngelo, L. (1981). Auditor size and auditor quality. Journal of Accounting and Economics 3(3), 183-199.

DeBerg, C., Kaplan, S., Pany, K. (1991). An examination of some relationships between non-audit services and auditor change. Accounting Horizons 5(1), 17-28. Dechow, P., Dechev, I. (2002). The quality of accruals and earnings: the role of accrual estimation errors. The Accounting Review 77(Supplement), 35-59.

DeFond, M., Raghunandan, K., Subramanyam, K. (2002). Do non-audit service fees impair audit independence? Evidence from going concern audit opinions. Journal of Accounting Research 40(4), 1247-1274.

Dhaliwal, D., Gleason, C., Heitzman, S., Melendrez, K. (2008). Auditor fees and cost of debt. Journal of Accounting, Auditing and Finance 23(1), 1-22.

Dopuch N., King, R., Schwartz, R. (2003). Independence in appearance and in fact: An experimental investigation. Contemporary Accounting Research 20(1), 79-114. 
Draper, P., Paudyal, K. (1999). Corporate takeovers: Mode of payment, returns and trading activity. Journal of Business Finance and Accounting 26(5/6), 521-558. Fargher, N., Jiang, L. (2008). Changes in the audit environments and auditors' propensity to issue going-concern opinion. Auditing: A Journal of Practice and Theory 27(2), 55-77.

Fearnley, S., Beattie, V. (2004). The reform of the UK's auditor independence framework after the Enron collapse: An example of evidence-based policy making. International Journal of Auditing 8(2), 117-138.

Ferguson, A., Francis, J., Stokes, D. (2003). The effects of firm-wide and office level industry expertise on audit pricing. The Accounting Review 78(2), 429-448.

Ferguson, M., Seow, G., Young, D. (2004). Nonaudit services and earnings management: UK evidence. Contemporary Accounting Research 21(4), 813-841. Ferguson, A., Stokes, D. (2002). Brand name audit pricing, industry specialisation, and leadership premiums post-Big 8 and Big 6 mergers. Contemporary Accounting Research 19(1), 77-100.

Firth, M. (1999). Company takeovers and the auditor choice decision. Journal of International Accounting, Auditing and Taxation 8(2), 197-214.

Francis, J. (1984). The effect of audit firm size on audit prices: A study of the Australian market. Journal of Accounting and Economics 6(2), 133-151.

Francis, J. (2004). What do we know about audit quality? British Accounting Review 36(4), 345-368.

Francis, J. (2006). Are auditors compromised by nonaudit services? Assessing the evidence. Contemporary Accounting Research 23(3), 747-760.

Francis, J., Ke, B. (2006). Disclosure of fees paid to auditors and the market valuation of earnings surprises. Review of Accounting Studies 11(4), 495-523. 
Francis, J., Reichelt, K., Wang, D. (2005).The pricing of national and city-specific reputations for industry expertise in the US audit market. The Accounting Review 80(1), 113-136.

Francis, J., Simon, D. (1987). A test of audit pricing in the small-client segment of the U.S. audit market. The Accounting Review 62(1), 145-157.

Francis, J., D. Stokes, D. (1986). Audit prices, product differentiation, and scale economies: Further evidence from the Australian market. Journal of Accounting Research 24(2), 383-393.

Francis, J., Wang, D. (2008). The joint effect of investor protection and Big 4 audits on earnings quality around the world. Contemporary Accounting Research 25(1), 157191.

Frankel, R., Johnson, M., Nelson, K. (2002). The relation between auditors’ fees for nonaudit services and earnings management. The Accounting Review 77 (Supplement), 71-105.

Franks, J., Harris, R., Mayer, C. (1988). Means of payment in takeovers: Results in the United Kingdom and the United States. In AJ Auerbach (Ed.), Corporate Takeovers: Causes and Consequences (pp. 221-264). University of Chicago Press, Chicago, IL.

Geiger, A., Rama, D. (2003). Audit fees, non-audit fees and auditor reporting on stressed companies. Auditing: A Journal of Practice and Theory 22(2), 53-69. Ghosh, A., Kallapur, S., Moon, D. (2009). Auditor and non-audit fees and capital market perceptions of auditor independence. Journal of Accounting and Public Policy 28(5), 369-385.

Gist. W. (1992). Explaining variability in external audit fees. Accounting and Business Research 23(Winter), 79-84. 
Glezen G., Millar, J. (1985). An empirical investigation of stockholder reaction to disclosures required by ASR No. 250. Journal of Accounting Research 23(2), 859870.

Gujarati, D. (1995). Basic Econometrics.(3 ${ }^{\text {rd }}$ ed.). Sydney: McGraw-Hill.

Gul., F., Jaggi, B., Krishnan, G. (2007). Auditor independence: Evidence on the joint effects of auditor tenure and nonaudit fees. Auditing: A Journal of Practice and Theory 26(2), 117-142.

Gul, F., Tsui, J., Dhaliwal, D. (2006). Non-audit services, auditor quality and the value relevance of earnings. Accounting and Finance 46(5), 797-817.

Harford J. (2003). Takeover bids and target directors' incentives: the impact of a bid on directors' wealth and board seats. Journal of Financial Economics 69(1), 51-83. Hay. D., Knechel, R. Li, V. (2006). Non-audit services and auditor independence: New Zealand evidence. Journal of Business Finance and Accounting 33(5/6), 715734.

Henry, D. (2005). Directors’ recommendations in takeovers: An agency and governance analysis. Journal of Business Finance and Accounting 32(1\&2), 129-159. Hietala, P., Kaplan, S., Robinson, D. (2003). What is the price of hubris? Using takeover battles to infer overpayments and synergies. Financial Management 32(3), 5-31.

Huang, Y., Walkling, R. (1987). Target abnormal returns associated with acquisition announcements: Payment acquisition form, and managerial resistance. Journal of Financial Economics 19(2), 329-349.

Israel, R. (1991). Capital structure and the market for corporate control: The defensive role of debt financing. The Journal of Finance 46(4), 1391-1409. 
Israel, R. (1992). Capital and ownership structures, and the market for corporate control. Review of Financial Studies 5(2), 181-198.

Khurana, I., Raman, K. (2006). Do investors care about the auditor’s economic dependence on the client? Contemporary Accounting Research 23(4), 977-1016. Kinney, W., Palmrose, Z., Scholz, S. (2004). Auditor independence, non-audit services, and restatements: Was the U.S. government right? Journal of Accounting Research 42(3), 561-588.

Klein, B., Leffler, K. (1981). The role of market forces in assuring contractual performance. Journal of Political Economy 89(4), 615-641.

Krishnamurthy, S., Zhou, J., Zhou, N. (2006). Auditor reputation, auditor independence, and the stock-market impact of Andersen's indictment on its client firms. Contemporary Accounting Research 23(2), 465-490.

Krishnan, G. (2003). Audit quality and the pricing of discretionary accruals. Auditing: A Journal of Practice \& Theory 22(1), 109-126.

Krishnan, J., Sami, H., Zhang, Y. (2005). Does the provision of nonaudit services affect investor perceptions of auditor independence? Auditing: A Journal of Practice \& Theory 24(2), 111-135.

Larcker, D., Richardson, S. (2004). Fees paid to audit firms, accrual choices, and corporate governance. Journal of Accounting Research 42(3), 625-658. Lee, P., Stokes, D., Taylor, S., Walter, T. (2003). The association between audit quality, accounting disclosures and firm-specific risk: Evidence from initial public offerings. Journal of Accounting and Public Policy 22(5), 377-400. Levitt, A. (2000). Renewing the covenant with investors, speech at the New York University Centre for Law and Business, May 10, available on the internet at http://www.sec.gov/news/speech/spch370.htm. Accessed 17.11.06. 
Li, C. (2009). Does client importance affect auditor independence at the office level? Empirical evidence from going-concern opinions. Contemporary Accounting Research 26(1), 201-230.

Lim, C., Tan, H. (2008). Non-audit service fees and audit quality: The impact of auditor specialization. Journal of Accounting Research 46(1), 199-246.

Louis, H. (2005). Acquirers' abnormal returns and the non-Big 4 auditor clientele effect. Journal of Accounting and Economics 40(1/3), 75-99.

Lys T., Watts, R. (1994). Lawsuits against auditors. Journal of Accounting Research 32 (Supplement), 65-93.

Menon, K., Williams, D. (1991). Auditor credibility and initial public offerings. The Accounting Review 66(2), 313-332.

Morck, R., Shleifer, A., Vishny, R. (1990). Do managerial objectives drive bad acquisitions? The Journal of Finance 45(1), 31-48.

Palmrose, Z. (1986). Audit fees and auditor size: Further evidence. Journal of Accounting Research 24(1), 97-110.

Palmrose, Z. (1988). An analysis of auditor litigation and audit service quality. The Accounting Review 63(1), 55-73.

Pong, C., Whittington, G. (1994). The determinants of audit fees: Some empirical models. Journal of Business Finance and Accounting 21(8), 1071-1095.

Qantas Airways Limited (2007).Target Statement, available on the internet at http://www.asx.com.au/asx/statistics/announcements.do?by=asxCode\&asxCode=qan \&timeframe=Y\&year=2007. Accessed 15.04.08.

Raad, E., Ryan, R., Sinkey, J. (1999). Leverage, ownership structure, and returns to shareholders of target and bidding firms. Quarterly Journal of Business and Economics 38(2), 37-53. 
Raman, K., Shivakumar, L., Tamayo, A. (2008). Targets earnings quality and bidders’ takeover decisions. Working paper, Bentley College.

Reichelt, K., Wang, D. (2010). National and office-specific measures of auditor industry expertise and effects on audit quality. Journal of Accounting Research 48(3), 647-686.

Reynolds, J., Deis, D., Francis, J. (2004). Professional service fees and auditor objectivity. Auditing: A Journal of Practice \& Theory 23(1), 29-52.

Reynolds, J., Francis, J. (2001). Does size matter? The influence of large clients on office-level auditor reporting decisions. Journal of Accounting and Economics 30(3), $375-400$.

Robinson, D. (2008). Auditor independence and auditor-provided tax service: Evidence from going-concern audit opinions prior to bankruptcy filings. Auditing: A Journal of Practice and Theory 27(2), 31-54.

Ruddock, C., Taylor, S., Taylor, S. (2006). Nonaudit services and earnings conservatism: Is auditor independence impaired? Contemporary Accounting Research 23(3), 701-746.

Schwert, G. (2000). Hostility in takeovers: In the eyes of the beholder? The Journal of Finance 55(6), 2599-2640.

Securities and Exchange Commission (SEC) 2000 Hearing on auditor independence July 26, 2000, available on the internet at http://www.sec.gov/rules/extra/audmin.htm. Accessed 17.11.06.

Shapiro, C. (1983). Premiums for high quality products as returns to reputations. The Quarterly Journal of Economics 98(4), 659-679 
Sharma, D. (2001). The association between nonaudit services and the propensity of going concern qualifications: Implications for auditor independence. Asia-Pacific Journal of Accounting and Economics 8(2), 143-156.

Sharma, D., Sidhu, J. (2001). Professionalism versus commercialism: The association between non-audit services (NAS) and audit independence. Journal of Business Finance and Accounting 28(5-6), 595-629.

Simunic, D. (1984). Auditing, consulting and auditor independence. Journal of Accounting Research 22(2), 679-702.

Srinidhi, B., Gul, F. (2007). The differential effects of auditors' nonaudit and audit fees on accrual quality. Contemporary Accounting Research 24(2), 595-629.

Stulz, R. (1988). Managerial control of voting rights: Financing policies and the market for corporate control. Journal of Financial Economics 20(1/2), 25-54.

Stulz, R., Walkling, R., Song, M. (1990). The distribution of target ownership and the division of gains in successful takeovers. The Journal of Finance 45(3), 817-833. Sudarsanam, S., Holl, P., Salami, A. (1996). Shareholder wealth gains in mergers: Effect of synergy and ownership structure. Journal of Business Finance and Accounting 23(2), 673-698.

White, H. (1980). A heteroscedasticity consistent covariance matrix estimator and a direct test of heteroscedasticity. Econometrica 48(4), 817-818.

Wines, G. (1994). Auditor independence, audit qualifications and the provision of non-audit services: a note. Accounting and Finance 34(1), 75-86. 


\section{Table 1}

\section{Time and industry distribution of sample}

Takeovers announced for ASX listed targets between 1996 and 2006 are identified from the Connect 4 Mergers and Acquisitions Database. The year of takeover refers to the year in which the takeover was announced. The attitude of the target firm board is based on the initial recommendation of the target firm board to shareholders.

\begin{tabular}{|c|c|c|c|c|c|}
\hline \multicolumn{6}{|c|}{ Panel A: Year distribution and attitude } \\
\hline Year & & Friendly & Hostile & & Total \\
\hline 1996 & & $25(41 \%)$ & $36(59 \%)$ & & 61 \\
\hline 1997 & & $24(62 \%)$ & $15(38 \%)$ & & 39 \\
\hline 1998 & & $25(47 \%)$ & $28(53 \%)$ & & 53 \\
\hline 1999 & & 18 (38\%) & $29(62 \%)$ & & 47 \\
\hline 2000 & & $29(50 \%)$ & $29(50 \%)$ & & 58 \\
\hline 2001 & & 31 (62\%) & $19(38 \%)$ & & 50 \\
\hline 2002 & & $22(50 \%)$ & $22(50 \%)$ & & 44 \\
\hline 2003 & & $26(53 \%)$ & $23(47 \%)$ & & 49 \\
\hline 2004 & & $20(49 \%)$ & $21(51 \%)$ & & 41 \\
\hline 2005 & & 22 (61\%) & $14(39 \%)$ & & 36 \\
\hline 2006 & & $42(61 \%)$ & 27 (39\%) & & 69 \\
\hline Total & & $284(52 \%)$ & $263(48 \%)$ & & 547 \\
\hline \multicolumn{6}{|c|}{ Panel B: Industry distribution of targets } \\
\hline ASX Industry & No. & Percentage & ASX Industry & No. & Percentage \\
\hline $\begin{array}{l}1 \text { Mining - Gold } \\
2 \text { Mining - }\end{array}$ & 70 & $13 \%$ & 13 Retail & 23 & $4 \%$ \\
\hline Other Metals & 33 & $6 \%$ & 14 Transport & 12 & $2 \%$ \\
\hline 3 Solid Fuels & 7 & $1 \%$ & 15 Media & 24 & $4 \%$ \\
\hline 4 Energy & 28 & $5 \%$ & 16 Banks & 0 & $0 \%$ \\
\hline $\begin{array}{l}5 \text { Infrastructure } \\
\text { and Utilties } \\
6 \text { Developers }\end{array}$ & 16 & $3 \%$ & 17 Insurance & 7 & $1 \%$ \\
\hline $\begin{array}{l}\text { and Contractors } \\
7 \text { Building }\end{array}$ & 15 & $3 \%$ & $\begin{array}{l}18 \text { Telecommunications } \\
19 \text { Investment and }\end{array}$ & 24 & $4 \%$ \\
\hline $\begin{array}{l}\text { Materials } \\
8 \text { Alcohol and }\end{array}$ & 14 & $3 \%$ & Financial Services & 40 & $7 \%$ \\
\hline $\begin{array}{l}\text { Tobacco } \\
9 \text { Food and }\end{array}$ & 16 & $3 \%$ & $\begin{array}{l}20 \text { Property Trusts } \\
21 \text { Healthcare and }\end{array}$ & 24 & $4 \%$ \\
\hline Household & 21 & $4 \%$ & $\begin{array}{l}\text { Biotechnology } \\
22 \text { Miscellaneous }\end{array}$ & 22 & $4 \%$ \\
\hline 10 Chemicals & 6 & $1 \%$ & $\begin{array}{l}\text { Industrials } \\
23 \text { Diversified }\end{array}$ & 90 & $16 \%$ \\
\hline $\begin{array}{l}11 \text { Engineering } \\
12 \text { Paper and }\end{array}$ & 10 & $2 \%$ & Industrials & 15 & $3 \%$ \\
\hline Packaging & 4 & $1 \%$ & 24 Tourism and Leisure & 26 & $5 \%$ \\
\hline
\end{tabular}


Table 2

\section{Descriptive statistics}

This table presents descriptive statistics for the variables in model (1) for the entire sample and separately by auditor size. A test of statistical difference across auditor size for each variable is also shown. A $t$-test is used for continuous variables and a $\chi^{2}$-test for binary variables. PREM is the abnormal return over the event window $(-60,+30)$ days around the takeover announcement. Auditor independence is measured using three variables: RNASTOT is the ratio of NAS fees to total fees, RNASAUD is the ratio of NAS fees to audit fees and LNNAS is the natural logarithm of NAS fees. $A U D R E P$ is a binary variable noting firms audited by a Big 4 auditor. QUALIFIED is an indicator variable noting target firms which received a qualified audit report, $P A Y T$ is an indicator variable set to 1 if the payment form is exclusively cash, MULTIPLE is an indicator variable set to 1 if there are multiple bidders for the target firm and $A C O V$ is an indicator variable set to 1 if the target firm has analyst coverage. TOEHOLD is the ownership interest of the bidding firm in the target at the announcement of the takeover. EARNQUAL is the ratio of cash flow from operations to net profit after tax, TGTSIZE is the natural logarithm of the target firm's market capitalisation, $D E$ is the target firm's debt-to-equity ratio, $R O E$ is the target firm's return on equity ratio, $M B$ is the target firm's market-tobook ratio and $A L T Z$ is the Altman Z-score. All accounting and auditing variables are collected from the financial statements released before the takeover announcement.

\begin{tabular}{lcccccc}
\hline Variable & Mean & Median & Std dev & Big 4 & Non-Big 4 & Stat diff \\
\hline PREM & 0.2729 & 0.2300 & 0.3755 & 0.2936 & 0.2077 & $2.39^{* *}$ \\
RNASTOT & 0.3442 & 0.3202 & 0.2404 & 0.3641 & 0.2816 & $3.53^{* * *}$ \\
RNASAUD & 0.9170 & 0.4710 & 1.3846 & 1.0096 & 0.6267 & $3.76^{* * *}$ \\
LNNAS & 9.5123 & 10.6690 & 3.9358 & 9.9712 & 7.9037 & $5.22^{* * *}$ \\
AUDREP & 0.7557 & 1.0000 & 0.4299 & - & - & - \\
QUALIFIED & 0.0841 & 0.0000 & 0.2778 & 0.0726 & 0.1194 & -1.69 \\
EARNQUAL & 1.5795 & 0.8294 & 13.3303 & 1.0089 & 3.3381 & -1.23 \\
PAYT & 0.6737 & 1.0000 & 0.4684 & 0.6998 & 0.6119 & 1.89 \\
TOEHOLD & 0.1687 & 0.1272 & 0.2121 & 0.1903 & 0.1507 & 1.50 \\
MULTIPLE & 0.2462 & 0.0000 & 0.4299 & 0.2591 & 0.1940 & 1.53 \\
DE & 1.2854 & 0.7243 & 4.8934 & 1.8340 & 1.0420 & 1.44 \\
ROE & -0.0071 & 0.0541 & 2.1900 & 0.0306 & -0.0946 & 0.98 \\
MB & 2.6947 & 1.2369 & 13.5685 & 3.3358 & 2.1443 & 1.26 \\
TGTSIZE & 17.8251 & 17.7438 & 1.7674 & 18.0621 & 17.0948 & $6.55^{* * *}$ \\
ACOV & 0.4962 & 0.0000 & 0.5005 & 0.5400 & 0.2910 & $5.36 * * *$ \\
ALTZ & 0.9028 & 0.6258 & 0.8645 & 0.9550 & 0.7836 & $2.26^{* *}$ \\
\hline \multirow{2}{*}{$* * *$ Significant at the 1\% level } & & $* *$ Significant at the 5\% level & & \\
& & & & &
\end{tabular}


Table 3

Correlation coefficients and two-tailed $p$-values for the dependent and independent variables in the takeover premium model

Correlation coefficients for the variables in model (1). PREM is the abnormal return over the event window (-60,+30) days around the takeover announcement. Auditor independence is measured using three variables: RNASTOT is the ratio of NAS fees to total fees, RNASAUD is the ratio of NAS fees to audit fees and LNNAS is the natural logarithm of NAS fees. AUDREP is a binary variable noting firms audited by a Big 4 auditor. QUALIFIED is an indicator variable noting target firms which received a qualified audit report, $P A Y T$ is an indicator variable set to 1 if the payment form is exclusively cash, MULTIPLE is an indicator variable set to 1 if there are multiple bidders for the target firm and ACOV is an indicator variable set to 1 if the target firm has analyst coverage. TOEHOLD is the ownership interest of the bidding firm in the target at the announcement of the takeover. EARNQUAL is the ratio of cash flow from operations to net profit after tax, TGTSIZE is the natural logarithm of the target firm's market capitalisation, $D E$ is the target firm's debt-to-equity ratio, $R O E$ is the target firm's return on equity ratio, $M B$ is the target firm's market-to-book ratio and $A L T Z$ is the Altman $Z$-score. FRIENDLY is an indicator variable set to 1 if the directors recommend bid acceptance. All accounting and auditing variables are collected from the financial statements released before the takeover announcement. Pearson correlations are below the diagonal and Spearman correlations are above.

\begin{tabular}{|c|c|c|c|c|c|c|c|c|c|c|c|c|c|c|c|c|c|}
\hline & PREM & RNASTOT & RNASAUD & LNNAS & AUDREP & QUALIFIED & EARNQUAL & PAYT & TOEHOLD & MULTIPLE & $D E$ & $R O E$ & $M B$ & $\begin{array}{l}\text { TGTSIZE } \\
\end{array}$ & $A C O V$ & ALTZ & FRIENDLY \\
\hline PREM & 1 & .069 & .069 & $.130^{* * * *}$ & $0.080^{*}$ & $-.113^{* *}$ & .062 & $.181^{* *}$ & .019 & .044 & .064 & .003 & -.047 & $.135^{* * * *}$ & $.190^{* * * *}$ & .052 & $0.033^{* * * *}$ \\
\hline RNASTOT & .029 & 1 & $1.000^{* * *}$ & $.766 * * *$ & $.147 * * *$ & -.038 & -.007 & -.013 & .005 & .012 & .047 & $.101^{* *}$ & .015 & $.187^{* * *}$ & $.210^{* * *}$ & -.052 & -.037 \\
\hline RNASAUD & -.018 & $.777 * * *$ & 1 & $.766 * * *$ & $.147 * * *$ & -.038 & -.007 & -.013 & .005 & .012 & .047 & $.101 * *$ & .015 & $.187 * * *$ & $.210^{* * * *}$ & -.052 & -.037 \\
\hline LNNAS & .076 & $.715^{* * * *}$ & $.413^{* * * *}$ & 1 & $.327^{* * * *}$ & $-.089 * *$ & $0.081^{*}$ & .053 & -.030 & .006 & $.221^{* * *}$ & $.172^{* * * *}$ & -.011 & $.509 * * *$ & $.464^{* * * *}$ & $.136 * * *$ & -.005 \\
\hline AUDREP & $.098^{* *}$ & $.148 * * *$ & $.120^{* * *}$ & $.227 * * *$ & 1 & $-0.072^{*}$ & .013 & $0.081^{*}$ & $0.071^{*}$ & .065 & .029 & $0.071^{*}$ & -.061 & $.241^{* * *}$ & $.211^{* * *}$ & $0.074^{*}$ & .022 \\
\hline QUALIFIED & $-0.0861^{*}$ & -.034 & -.024 & -.059 & $-0.072 *$ & 1 & $-.085^{* *}$ & $-0.073^{*}$ & -.036 & .043 & .015 & $-.224^{* * *}$ & -.005 & $-.217 * * *$ & $-0.109 * *$ & $-0.162 * * *$ & .067 \\
\hline EARNQUAL & .030 & -.030 & -.020 & -.007 & $-0.075^{*}$ & -.008 & 1 & .024 & -.033 & .003 & .038 & $.278^{* * *}$ & .048 & $.199 * * *$ & $.136 * * *$ & .014 & -.011 \\
\hline PAYT & $.150 * * *$ & -.016 & -.013 & .028 & $0.081^{*}$ & $-0.073 *$ & .024 & 1 & $.141^{* * * *}$ & $0.080^{*}$ & $0.080^{*}$ & .024 & $-.107 * *$ & -.017 & .027 & $.197 * * *$ & .019 \\
\hline TOEHOLD & -.028 & -.012 & -.011 & -.004 & .047 & -.030 & .010 & $.101^{* *}$ & 1 & $-.109 * *$ & $.123^{* * *}$ & -.017 & -.007 & -.041 & $-0.074^{*}$ & .060 & $0.080^{* *}$ \\
\hline MULTIPLE & .056 & .000 & -.019 & -.009 & .065 & .043 & -.039 & $0.080^{*}$ & $-.107 * *$ & 1 & .065 & -.033 & .023 & $0.079^{*}$ & $.098 * *$ & $-0.087 * *$ & $-.180^{* * *}$ \\
\hline$D E$ & .011 & .034 & .050 & -.014 & .036 & $.117 * * *$ & -.006 & -.034 & .031 & -.031 & 1 & $0.082^{*}$ & $.202 * * *$ & $.111^{* * * *}$ & $.168^{* * *}$ & $.338 * * *$ & .044 \\
\hline$R O E$ & -.059 & .041 & .019 & .060 & .025 & .015 & .004 & .007 & -.056 & -.024 & $.147^{* * *}$ & 1 & $.146^{* * *}$ & $.360^{* * *}$ & $.158^{* * *}$ & $.208^{* * *}$ & .026 \\
\hline$M B$ & -.032 & -.002 & .020 & -.051 & .032 & .068 & -.010 & -.019 & .035 & -.046 & $.493^{* * *}$ & .067 & 1 & $.281^{* * *}$ & -.024 & $0.076^{*}$ & .017 \\
\hline TGTSIZE & .049 & $.174 * * *$ & $.133^{* * * *}$ & $.335^{* * * *}$ & $.216^{* * * *}$ & $-.191^{* * *}$ & .024 & -.036 & -.006 & $0.080^{*}$ & $-.092 * *$ & .058 & -.063 & 1 & $.628 * * *$ & .019 & .008 \\
\hline$A C O V$ & $.136 * * *$ & $208 * * *$ & $.157 * * *$ & $.344 * * *$ & $.211^{* * * *}$ & $-.108 * *$ & .013 & .027 & -.016 & $.098 * *$ & -.040 & $.087 * *$ & .071 & $.531 * * *$ & 1 & .063 & -.004 \\
\hline ALTZ & .054. & -0.049 & -.060 & $.097 * *$ & $.083^{*}$ & $-.109 * *$ & .035 & $.131^{* * *}$ & .032 & $-.098 * *$ & $.090 * *$ & -.022 & .058 & -.027 & .033 & 1 & $.082 * *$ \\
\hline FRIENDLY & .031 & -.037 & -.001 & -.011 & .022 & .067 & $-0.07 *$ & .019 & $.150 * * *$ & $-.180 * * *$ & 0.073* & $0.078^{*}$ & .005 & .018 & -.004 & .045 & 1 \\
\hline
\end{tabular}

*** Significant at the $1 \%$ level ** Significant at the $5 \%$ level * Significant at the $10 \%$ level 
Table 4

Model of takeover premiums and auditor independence and reputation

Results of estimating model (1): $P R E M_{\mathrm{i}}=\alpha_{\mathrm{i}}+\beta_{1} A U D I N D E P_{\mathrm{i}}+\beta_{2} A U D R E P_{\mathrm{i}}+\beta_{3}$ QUALIFIED $_{\mathrm{i}}+\beta_{4}$ EARNQUAL $_{\mathrm{i}}$ $+\beta_{5}$ PAYT $_{\mathrm{i}}++\beta_{6}$ TOEHOLD $_{\mathrm{i}}+\beta_{7}$ MULTIPLE $_{\mathrm{i}}+\beta_{8} D E_{\mathrm{i}}+\beta_{9} R O E_{\mathrm{i}}+\beta_{10} M_{\mathrm{i}}+\beta_{11}$ TGTSIZE $_{\mathrm{i}}+\beta_{12}$ ACOV $_{\mathrm{i}}+$ $\beta_{13} A L T Z_{\mathrm{i}}+\varepsilon_{\mathrm{i}}$. PREM is the abnormal return over the event window $(-60,+30)$ days around the takeover announcement. Auditor independence is measured using three variables: RNASTOT is the ratio of NAS fees to total fees, RNASAUD is the ratio of NAS fees to audit fees and LNNAS is the natural logarithm of NAS fees. AUDREP is a binary variable noting firms audited by a Big 4 auditor. QUALIFIED is an indicator variable noting target firms which received a qualified audit report, $P A Y T$ is an indicator variable set to 1 if the payment form is exclusively cash, MULTIPLE is an indicator variable set to 1 if there are multiple bidders for the target firm and $A C O V$ is an indicator variable set to 1 if the target firm has analyst coverage. TOEHOLD is the ownership interest of the bidding firm in the target at the announcement of the takeover. EARNQUAL is the ratio of cash flow from operations to net profit after tax, TGTSIZE is the natural logarithm of the target firm's market capitalisation, $D E$ is the target firm's debt-to-equity ratio, $R O E$ is the target firm's return on equity ratio, $M B$ is the target firm's marketto-book ratio and $A L T Z$ is the Altman $Z$-score. All accounting and auditing variables are collected from the financial statements released before the takeover announcement. Industry and year indicator variables are also included in the model but the results are not reported. $t$-statistics are in parentheses.

\begin{tabular}{|c|c|c|c|c|}
\hline Variable & $(1)$ & $(2)$ & (3) & (4) \\
\hline \multicolumn{5}{|c|}{ Panel A: Hostile takeovers $(n=263)$} \\
\hline Intercept & $\begin{array}{c}0.0104 \\
(0.07)\end{array}$ & $\begin{array}{c}0.0113 \\
(0.08)\end{array}$ & $\begin{array}{c}0.0025 \\
(0.02)\end{array}$ & $\begin{array}{c}0.0076 \\
(0.05)\end{array}$ \\
\hline RNASTOT & $\begin{array}{l}0.0009 \\
(0.01)\end{array}$ & - & - & - \\
\hline RNASAUD & - & $\begin{array}{c}-0.0103 \\
(-0.55)\end{array}$ & - & - \\
\hline LNNAS & - & - & $\begin{array}{c}0.0038 \\
(0.60)\end{array}$ & - \\
\hline AUDREP & - & - & - & $\begin{array}{l}0.0834 \\
(1.73)^{*}\end{array}$ \\
\hline QUALIFIED & $\begin{array}{c}-0.0554 \\
(-0.73)\end{array}$ & $\begin{array}{c}-0.0530 \\
(-0.70)\end{array}$ & $\begin{array}{c}-0.0594 \\
(-0.76)\end{array}$ & $\begin{array}{l}-0.0528 \\
(-0.68)\end{array}$ \\
\hline EARNQUAL & $\begin{array}{c}-0.0009 \\
(-2.38)^{* *}\end{array}$ & $\begin{array}{c}-0.0010 \\
(-2.49)^{* *}\end{array}$ & $\begin{array}{c}-0.0009 \\
(-2.43)^{* *}\end{array}$ & $\begin{array}{l}-0.0708 \\
(-1.68)^{*}\end{array}$ \\
\hline PAYT & $\begin{array}{c}0.1720 \\
(3.49)^{* * *}\end{array}$ & $\begin{array}{c}0.1737 \\
(3.55)^{* * *}\end{array}$ & $\begin{array}{c}0.1708 \\
(3.47)^{* * *}\end{array}$ & $\begin{array}{c}0.1685 \\
(3.45)^{* * *}\end{array}$ \\
\hline TOEHOLD & $\begin{array}{c}-0.0421 \\
(-2.61)^{* * *}\end{array}$ & $\begin{array}{c}-0.0427 \\
(-2.69)^{* *}\end{array}$ & $\begin{array}{c}-0.0416 \\
(-2.59)^{* * *}\end{array}$ & $\begin{array}{c}-0.0436 \\
(-2.70)^{* * *}\end{array}$ \\
\hline MULTIPLE & $\begin{array}{c}0.0553 \\
(1.20)\end{array}$ & $\begin{array}{c}0.0549 \\
(1.19)\end{array}$ & $\begin{array}{c}0.0564 \\
(1.22)\end{array}$ & $\begin{array}{c}0.0522 \\
(1.33)\end{array}$ \\
\hline$D E$ & $\begin{array}{c}0.0503 \\
(2.19)^{* *}\end{array}$ & $\begin{array}{c}0.0496 \\
(2.16)^{* *}\end{array}$ & $\begin{array}{c}0.0481 \\
(2.11)^{* *}\end{array}$ & $\begin{array}{c}0.0470 \\
(2.06)^{* *}\end{array}$ \\
\hline$R O E$ & $\begin{array}{c}0.0421 \\
(1.44)\end{array}$ & $\begin{array}{c}0.0412 \\
(1.40)\end{array}$ & $\begin{array}{c}0.0382 \\
(1.32)\end{array}$ & $\begin{array}{c}0.0384 \\
(1.31)\end{array}$ \\
\hline$M B$ & $\begin{array}{c}-0.0171 \\
(-2.13)^{* *}\end{array}$ & $\begin{array}{c}-0.0169 \\
(-2.09)^{* *}\end{array}$ & $\begin{array}{c}-0.0164 \\
(-2.05)^{* *}\end{array}$ & $\begin{array}{c}-0.0160 \\
(-2.00)^{* *}\end{array}$ \\
\hline TGTSIZE & $\begin{array}{c}0.0086 \\
(1.06)\end{array}$ & $\begin{array}{c}0.0090 \\
(1.11)\end{array}$ & $\begin{array}{c}0.0073 \\
(0.88)\end{array}$ & $\begin{array}{c}0.0067 \\
(0.79)\end{array}$ \\
\hline$A C O V$ & $\begin{array}{l}0.0527 \\
(1.11)\end{array}$ & $\begin{array}{l}0.0574 \\
(1.21)\end{array}$ & $\begin{array}{c}0.0459 \\
(0.95)\end{array}$ & $\begin{array}{c}0.0445 \\
(0.90)\end{array}$ \\
\hline$A L T Z$ & $\begin{array}{c}-0.0728 \\
(-2.65) * * *\end{array}$ & $\begin{array}{c}-0.0747 \\
(-2.76)^{* * *}\end{array}$ & $\begin{array}{c}-0.0734 \\
(-2.73) * * *\end{array}$ & $\begin{array}{c}-0.0769 \\
(-2.86)^{* * *}\end{array}$ \\
\hline Adjusted $\mathrm{R}^{2}$ & 0.0764 & 0.0776 & 0.0778 & 0.0820 \\
\hline F-stat & $2.751 * * *$ & $2.780 * * *$ & $2.786 * * *$ & $2.890 * * *$ \\
\hline
\end{tabular}

*** Significant at the $1 \%$ level

* Significant at the $10 \%$ level

** Significant at the $5 \%$ level 
Table 4 - continued

\begin{tabular}{|c|c|c|c|c|}
\hline Variable & (1) & (2) & (3) & (4) \\
\hline \multicolumn{5}{|c|}{ Panel B: Friendly takeovers $(n=284)$} \\
\hline \multirow[t]{2}{*}{ Intercept } & 0.7865 & 0.7822 & 0.7897 & 0.7901 \\
\hline & $(2.20) * *$ & $(2.18)^{* *}$ & $(2.14)^{* *}$ & $(2.20) * *$ \\
\hline \multirow[t]{2}{*}{ RNASTOT } & -0.0110 & - & - & - \\
\hline & $(-0.10)$ & & & \\
\hline \multirow[t]{2}{*}{ RNASAUD } & - & -0.0114 & - & - \\
\hline & & $(-0.34)$ & & \\
\hline \multirow[t]{2}{*}{ LNNAS } & - & - & 0.0009 & - \\
\hline & & & $(0.13)$ & \\
\hline \multirow[t]{2}{*}{ AUDREP } & - & - & - & 0.0539 \\
\hline & & & & $(0.95)$ \\
\hline \multirow[t]{2}{*}{ QUALIFIED } & -0.1357 & -0.1381 & -0.1356 & -0.1359 \\
\hline & $(-1.61)$ & $(-1.65)$ & $(-1.60)$ & $(-1.63)$ \\
\hline \multirow[t]{2}{*}{ EARNQUAL } & 0.0044 & 0.0044 & 0.0044 & 0.0045 \\
\hline & $(2.54)^{* *}$ & $(2.55)^{* *}$ & $(2.54)^{* *}$ & $(2.62)^{* * *}$ \\
\hline \multirow[t]{2}{*}{$P A Y T$} & 0.0777 & 0.0770 & 0.0780 & 0.0750 \\
\hline & $(1.40)$ & (1.39) & (1.41) & (1.36) \\
\hline \multirow[t]{2}{*}{ TOEHOLD } & -0.0702 & -0.0697 & -0.0703 & -0.0771 \\
\hline & $(-0.82)$ & $(-0.82)$ & $(-0.82)$ & $(-0.89)$ \\
\hline \multirow[t]{2}{*}{ MULTIPLE } & -0.0051 & -0.0077 & -0.0044 & -0.0078 \\
\hline & $(-0.09)$ & $(-0.14)$ & $(-0.81)$ & $(-0.14)$ \\
\hline \multirow[t]{2}{*}{$D E$} & 0.0322 & 0.0323 & 0.0322 & 0.0330 \\
\hline & $(2.32)^{* *}$ & $(2.35)^{* *}$ & $(2.34)^{* *}$ & $(2.40)^{* *}$ \\
\hline \multirow[t]{2}{*}{$R O E$} & -0.0152 & -0.0153 & -0.0153 & -0.0153 \\
\hline & $(-4.93) * * *$ & $(-4.98) * * *$ & $(-4.87) * * *$ & $(-4.78) * * *$ \\
\hline \multirow[t]{2}{*}{$M B$} & -0.0124 & -0.0125 & -0.0124 & -0.0127 \\
\hline & $(-2.53)^{* *}$ & $(-2.56)^{* *}$ & $(-2.54) * *$ & $(-2.61)^{* * *}$ \\
\hline \multirow[t]{2}{*}{ TGTSIZE } & -0.0360 & -0.0354 & -0.0368 & -0.0384 \\
\hline & $(-1.80)^{*}$ & $(-1.77)^{*}$ & $(-1.70)^{*}$ & $(-1.87)^{*}$ \\
\hline \multirow[t]{2}{*}{$A C O V$} & 0.1629 & 0.1653 & 0.1610 & 0.1585 \\
\hline & $(2.66) * * *$ & $(2.70)^{* * *}$ & $(2.64) * * *$ & $(2.62)^{* * *}$ \\
\hline \multirow[t]{2}{*}{$A L T Z$} & 0.0316 & 0.0307 & 0.0311 & 0.0306 \\
\hline & $(0.83)$ & $(0.81)$ & $(0.82)$ & $(0.81)$ \\
\hline Adjusted $\mathrm{R}^{2}$ & 0.0578 & 0.0597 & 0.0578 & 0.0609 \\
\hline F-stat & $2.359 * * *$ & $2.408 * * *$ & $2.360 * * *$ & $2.439 * * *$ \\
\hline
\end{tabular}


Table 5

Model of takeover premiums and auditor independence and reputation before and after auditing scandals

Results of estimating model (1) after the inclusion of an indicator variable denoting takeovers announced after 2001 (POST01). This dummy variable is interacted with the three measures of auditor independence and the auditor reputation variable. The dependent variable is the abnormal return over the event window $(-60,+30)$ days around the takeover announcement. Auditor independence is measured using three variables: RNASTOT is the ratio of NAS fees to total fees, RNASAUD is the ratio of NAS fees to audit fees and LNNAS is the natural logarithm of NAS fees. AUDREP is a binary variable noting firms audited by a Big 4 auditor. QUALIFIED is an indicator variable noting target firms which received a qualified audit report, $P A Y T$ is an indicator variable set to 1 if the payment form is exclusively cash, MULTIPLE is an indicator variable set to 1 if there are multiple bidders for the target firm and ACOV is an indicator variable set to 1 if the target firm has analyst coverage. TOEHOLD is the ownership interest of the bidding firm in the target at the announcement of the takeover. EARNQUAL is the ratio of cash flow from operations to net profit after tax, TGTSIZE is the natural logarithm of the target firm's market capitalisation, $D E$ is the target firm's debt-to-equity ratio, $R O E$ is the target firm's return on equity ratio, $M B$ is the target firm's market-to-book ratio and $A L T Z$ is the Altman Z-score. All accounting and auditing variables are collected from the financial statements released before the takeover announcement. Industry and year indicator variables are also included in the model but the results are not reported. $t$-statistics are in parentheses.

\begin{tabular}{|c|c|c|c|c|}
\hline Variable & (1) & $(2)$ & (3) & (4) \\
\hline \multicolumn{5}{|c|}{ Panel A: Hostile takeovers $(n=263)$} \\
\hline Intercept & $\begin{array}{c}0.0329 \\
(0.22)\end{array}$ & $\begin{array}{c}0.0113 \\
(0.08)\end{array}$ & $\begin{array}{c}0.0245 \\
(0.15)\end{array}$ & $\begin{array}{c}-0.0356 \\
(-0.23)\end{array}$ \\
\hline RNASTOT & $\begin{array}{c}-0.0478 \\
(-0.38)\end{array}$ & - & - & - \\
\hline RNASTOT*POST01 & $\begin{array}{c}0.0699 \\
(0.40)\end{array}$ & - & - & - \\
\hline RNASAUD & - & $\begin{array}{c}-0.0151 \\
(-0.62)\end{array}$ & - & - \\
\hline RNASAUD*POST01 & - & $\begin{array}{l}0.0002 \\
(0.01)\end{array}$ & - & - \\
\hline LNNAS & - & - & $\begin{array}{c}0.0023 \\
(0.24)\end{array}$ & - \\
\hline LNNAS*POST01 & & - & $\begin{array}{l}0.0042 \\
(0.38)\end{array}$ & - \\
\hline AUDREP & - & - & - & $\begin{array}{c}0.1722 \\
(2.53)^{* *}\end{array}$ \\
\hline AUDREP*POST01 & - & - & - & $\begin{array}{c}-0.2602 \\
(-2.87)^{* * *}\end{array}$ \\
\hline POST01 & $\begin{array}{c}-0.1032 \\
(-1.41)\end{array}$ & $\begin{array}{c}-0.0828 \\
(-1.59)\end{array}$ & $\begin{array}{c}-0.1185 \\
(-1.01)\end{array}$ & $\begin{array}{c}0.1180 \\
(1.52)\end{array}$ \\
\hline QUALIFIED & $\begin{array}{c}-0.0511 \\
(-0.66)\end{array}$ & $\begin{array}{c}-0.0520 \\
(-0.67)\end{array}$ & $\begin{array}{c}-0.0599 \\
(-0.76)\end{array}$ & $\begin{array}{c}-0.0490 \\
(-0.63)\end{array}$ \\
\hline EARNQUAL & $\begin{array}{c}-0.0011 \\
(-2.84)^{* *}\end{array}$ & $\begin{array}{c}-0.0012 \\
(-2.99)^{* * *}\end{array}$ & $\begin{array}{c}-0.0011 \\
(-2.94)^{* * *}\end{array}$ & $\begin{array}{c}-0.0007 \\
(-1.46)\end{array}$ \\
\hline PAYT & $\begin{array}{c}0.1756 \\
(3.53)^{* * *}\end{array}$ & $\begin{array}{c}0.1752 \\
(3.60)^{* * *}\end{array}$ & $\begin{array}{c}0.1742 \\
(3.46)^{* * *}\end{array}$ & $\begin{array}{c}0.1723 \\
(3.57)^{* * *}\end{array}$ \\
\hline TOEHOLD & $\begin{array}{c}-0.0510 \\
(-2.86)^{* * *}\end{array}$ & $\begin{array}{c}-0.0511 \\
(-2.93)^{* * *}\end{array}$ & $\begin{array}{c}-0.0499 \\
(-2.76)^{* * *}\end{array}$ & $\begin{array}{c}-0.0552 \\
(-3.23)^{* * *}\end{array}$ \\
\hline MULTIPLE & $\begin{array}{c}0.0584 \\
(1.29)\end{array}$ & $\begin{array}{c}0.0583 \\
(1.28)\end{array}$ & $\begin{array}{c}0.0600 \\
(1.32)\end{array}$ & $\begin{array}{c}0.0449 \\
(1.01)\end{array}$ \\
\hline$D E$ & $\begin{array}{c}0.0486 \\
(2.15)^{* *}\end{array}$ & $\begin{array}{c}0.0475 \\
(2.08)^{* *}\end{array}$ & $\begin{array}{c}0.0466 \\
(2.08)^{* *}\end{array}$ & $\begin{array}{l}0.0409 \\
(1.88)^{*}\end{array}$ \\
\hline ROE & $\begin{array}{l}0.0518 \\
(1.73)^{*}\end{array}$ & $\begin{array}{c}0.0490 \\
(1.61)\end{array}$ & $\begin{array}{c}0.0474 \\
(1.59)\end{array}$ & $\begin{array}{l}0.0439 \\
(1.46)\end{array}$ \\
\hline$M B$ & $\begin{array}{c}-0.0162 \\
(-2.03)^{* *}\end{array}$ & $\begin{array}{c}-0.0158 \\
(-1.97)^{* *}\end{array}$ & $\begin{array}{c}-0.0156 \\
(-1.97)^{* *}\end{array}$ & $\begin{array}{l}-0.0134 \\
(-1.75)^{*}\end{array}$ \\
\hline TGTSIZE & $\begin{array}{l}0.0100 \\
(1.28)\end{array}$ & $\begin{array}{l}0.0107 \\
(1.38)\end{array}$ & $\begin{array}{l}0.0086 \\
(1.08)\end{array}$ & $\begin{array}{l}0.0069 \\
(0.86)\end{array}$ \\
\hline$A C O V$ & $\begin{array}{l}0.0540 \\
(1.15)\end{array}$ & $\begin{array}{l}0.0585 \\
(1.26)\end{array}$ & $\begin{array}{l}0.0449 \\
(0.93)\end{array}$ & $\begin{array}{l}0.0470 \\
(0.97)\end{array}$ \\
\hline$A L T Z$ & $\begin{array}{c}-0.0715 \\
(-2.59) * * *\end{array}$ & $\begin{array}{c}-0.0732 \\
(-2.68)^{* * *}\end{array}$ & $\begin{array}{c}-0.0711 \\
(-2.63)^{* * *}\end{array}$ & $\begin{array}{c}-0.0819 \\
(-3.02)^{* * *}\end{array}$ \\
\hline Adjusted $\mathrm{R}^{2}$ & 0.0813 & 0.0830 & 0.0826 & 0.1115 \\
\hline F-stat & $2.605 * * *$ & $2.643 * * *$ & $2.634 * * *$ & $3.277 * * *$ \\
\hline
\end{tabular}

*** Significant at the $1 \%$ level ** Significant at the 5\% level * Significant at the $10 \%$ level 
Table 5 - continued

\begin{tabular}{|c|c|c|c|c|}
\hline \multicolumn{5}{|c|}{$\begin{array}{l}\text { Variable } \\
\text { Panel B: Friendly takeovers }(\mathrm{n}=284)\end{array}$} \\
\hline \multicolumn{5}{|c|}{ Panel B: Friendly takeovers $(n=284)$} \\
\hline Intercept & 0.8018 & 0.7847 & 0.7760 & 0.7926 \\
\hline & $(2.16)^{* *}$ & $(2.12)^{* *}$ & $(2.06)^{* *}$ & $(2.16)^{* *}$ \\
\hline RNASTOT & -0.0671 & - & - & - \\
\hline & $(-0.37)$ & & & \\
\hline RNASTOT*POST01 & $\begin{array}{c}0.1216 \\
(0.54)\end{array}$ & - & - & - \\
\hline RNASAUD & - & $\begin{array}{c}-0.0129 \\
(-0.33)\end{array}$ & - & - \\
\hline RNASAUD*POST01 & - & $\begin{array}{c}0.0116 \\
(0.23)\end{array}$ & - & - \\
\hline LNNAS & - & - & $\begin{array}{c}0.0049 \\
(0.41)\end{array}$ & - \\
\hline LNNAS*POST01 & & - & $\begin{array}{c}-0.0049 \\
(-0.37)\end{array}$ & - \\
\hline$A U D R E P$ & - & - & - & $\begin{array}{l}0.0571 \\
(0.82)\end{array}$ \\
\hline AUDREP $*$ POST01 & - & - & - & $\begin{array}{l}-0.0083 \\
(-0.08)\end{array}$ \\
\hline POST01 & $\begin{array}{c}-0.0321 \\
(-0.39)\end{array}$ & $\begin{array}{c}-0.0049 \\
(-0.08)\end{array}$ & $\begin{array}{l}0.0598 \\
(0.46)\end{array}$ & $\begin{array}{l}0.0133 \\
(0.14)\end{array}$ \\
\hline QUALIFIED & $\begin{array}{c}-0.1339 \\
(-1.58)\end{array}$ & $\begin{array}{c}-0.1369 \\
(-1.62)\end{array}$ & $\begin{array}{l}-0.1397 \\
(-1.61)\end{array}$ & $\begin{array}{c}-0.1364 \\
(-1.63)\end{array}$ \\
\hline EARNQUAL & $\begin{array}{c}0.0044 \\
(2.53)^{* *}\end{array}$ & $\begin{array}{c}0.0044 \\
(2.54)^{* *}\end{array}$ & $\begin{array}{l}0.0044 \\
(2.54)^{* *}\end{array}$ & $\begin{array}{c}0.0045 \\
(2.61)^{* * *}\end{array}$ \\
\hline PAYT & $\begin{array}{l}0.0813 \\
(1.46)\end{array}$ & $\begin{array}{c}0.0783 \\
(1.39)\end{array}$ & $\begin{array}{l}0.0756 \\
(1.36)\end{array}$ & $\begin{array}{l}0.0745 \\
(1.34)\end{array}$ \\
\hline TOEHOLD & $\begin{array}{c}-0.0679 \\
(-0.79)\end{array}$ & $\begin{array}{l}-0.0685 \\
(-0.79)\end{array}$ & $\begin{array}{l}-0.0676 \\
(-0.79)\end{array}$ & $\begin{array}{l}-0.0765 \\
(-0.88)\end{array}$ \\
\hline MULTIPLE & $\begin{array}{l}-0.0026 \\
(-0.05)\end{array}$ & $\begin{array}{l}-0.0072 \\
(-0.13)\end{array}$ & $\begin{array}{l}-0.0046 \\
(-0.08)\end{array}$ & $\begin{array}{l}-0.0087 \\
(-0.15)\end{array}$ \\
\hline$D E$ & $\begin{array}{c}0.0327 \\
(2.36)^{* *}\end{array}$ & $\begin{array}{c}0.0324 \\
(2.36)^{* *}\end{array}$ & $\begin{array}{c}0.0318 \\
(2.28)^{* *}\end{array}$ & $\begin{array}{c}0.0330 \\
(2.36)^{* *}\end{array}$ \\
\hline$R O E$ & $\begin{array}{c}-0.0154 \\
(-4.77)^{* * *}\end{array}$ & $\begin{array}{c}-0.0154 \\
(-4.97)^{* * *}\end{array}$ & $\begin{array}{c}-0.0151 \\
(-4.82)^{* * *}\end{array}$ & $\begin{array}{c}-0.0153 \\
(-4.75)^{* * *}\end{array}$ \\
\hline$M B$ & $\begin{array}{c}-0.0125 \\
(-2.56)^{* *}\end{array}$ & $\begin{array}{c}-0.0125 \\
(-2.57)^{* *}\end{array}$ & $\begin{array}{c}-0.0123 \\
(-2.50)^{* *}\end{array}$ & $\begin{array}{c}-0.0127 \\
(-2.55)^{* *}\end{array}$ \\
\hline TGTSIZE & $\begin{array}{l}-0.0362 \\
(-1.68)^{*}\end{array}$ & $\begin{array}{l}-0.0356 \\
(-1.67)^{*}\end{array}$ & $\begin{array}{c}-0.0386 \\
(-1.64)\end{array}$ & $\begin{array}{l}-0.0389 \\
(-1.81)^{*}\end{array}$ \\
\hline$A C O V$ & $\begin{array}{c}0.1653 \\
(2.60)^{* * *}\end{array}$ & $\begin{array}{c}0.1661 \\
(2.65)^{* * *}\end{array}$ & $\begin{array}{c}0.1624 \\
(2.57)^{* *}\end{array}$ & $\begin{array}{c}0.1611 \\
(2.53)^{* *}\end{array}$ \\
\hline$A L T Z$ & $\begin{array}{c}0.0317 \\
(0.84)\end{array}$ & $\begin{array}{c}0.0308 \\
(0.81)\end{array}$ & $\begin{array}{c}0.0302 \\
(0.78)\end{array}$ & $\begin{array}{l}0.0307 \\
(0.82)\end{array}$ \\
\hline Adjusted $\mathrm{R}^{2}$ & 0.0517 & 0.0526 & 0.0510 & 0.0536 \\
\hline F-stat & $2.036 * *$ & $2.054 * *$ & $2.021 * *$ & $2.076^{* *}$ \\
\hline
\end{tabular}

$* * *$ Significant at the $1 \%$ level

** Significant at the $5 \%$ level

* Significant at the $10 \%$ level 